\title{
Insect Management for Tomatoes, Peppers, and Eggplant ${ }^{1}$
}

\author{
S. E. Webb, P. A. Stansly, D. J. Schuster and J. E. Funderburk ${ }^{2}$
}

Pest management should be based on the proper identification of pests and knowledge of their biology. The major pests of tomatoes, peppers, and eggplant in Florida and guidelines for their management are described below. Some insects may be more important in some areas of the state than others. Scouting guidelines and action thresholds for tomatoes are from the Florida Tomato Scouting Guide, SP 22, 2nd edition.

For each pest described, a table of management options will be found after the damage. These tables will be expanded as more information becomes available. Tables 13-15, at the end of this publication, list pesticides labeled for each major fruiting vegetable grown in Florida: tomatoes, peppers, and eggplants. Pesticides for controlling insects not described below can be found by looking under the "Insects" column in the tables.

\section{Silverleaf Whitefly, Bemisia argentifolii}

\section{Description}

The adult silverleaf whitefly (Figure 1) is small, approximately $1 / 16$ of an inch in length, and has powdery white wings held tent-like over a yellow body while at rest. Whiteflies are usually found on the undersides of leaves, often in pairs. Males are smaller than females. Eggs, which are yellow and football-shaped, are attached upright by a tiny stalk inserted into the lower leaf surface. A mobile first instar or crawler stage hatches from the egg and settles on the leaf. It then develops through immobile second, third, and fourth instars, which look like semi-transparent, flat, oval scales. The fourth instar or "pupa" is more yellow and more easily seen without the aid of a hand lens, typically has very distinct eyespots, and is referred to as a "red-eyed nymph."

1. This document is ENY-461, one of a series of the Entomology \& Nematology Department, Florida Cooperative Extension Service, Institute of Food and Agricultural Sciences, University of Florida. Published: November 2001. Revised: August 2005. For more publications related to horticulture/agriculture, please visit the EDIS Website at http://edis.ifas.ufl.edu/.

2. S. E. Webb, associate professor, Gainesville, P. A. Stansly, professor, Immokalee, D. J. Schuster, professor, Bradenton, and J. E. Funderburk, professor, Quincy, Entomology and Nematology Department, Cooperative Extension Service, Institute of Food and Agricultural Sciences, University of Florida, Gainesville, 32611-0640.

The use of trade names in this publication is solely for the purpose of providing specific information. UF/IFAS does not guarantee or warranty the products named, and references to them in this publication does not signify our approval to the exclusion of other products of suitable composition. All chemicals should be used in accordance with directions on the manufacturer's label. Use pesticides safely. Read and follow directions on the manufacturer's label. 


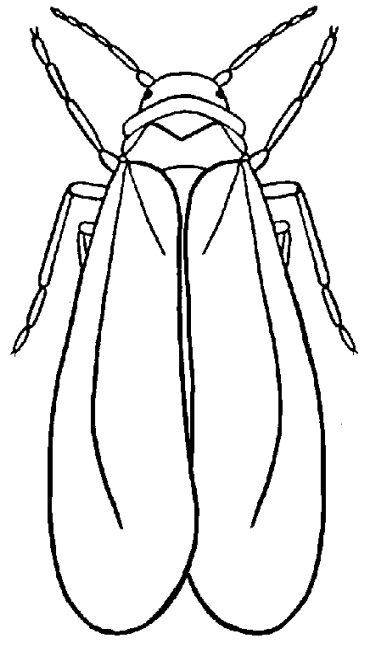

Figure 1. Silverleaf whitefly.

\section{Biology}

The life cycle from egg to adult can be as short as two weeks when the weather is very warm. Adult females lay most of their eggs on young leaves so young nymphs also generally occur on the underside of younger leaves. As the plant grows, leaves bearing the maturing nymphs are found lower down on the plant, so older nymphs can be found by looking at older leaves. Whiteflies feed in the plant vascular system (phloem) through a stylet similar to that of aphids and, like aphids, process a relatively large volume of plant sap by excreting excess liquid in the form of a sugary substance called honeydew.

\section{Damage}

Heavy whitefly populations can damage plants directly by removing sap. The honeydew that they excrete while feeding serves as food for sooty mold, which can reduce the amount of light reaching leaves. Moderate numbers of nymphs can cause irregular ripening of tomatoes, characterized by incomplete ripening of longitudinal sections of fruit. Nymphal feeding also causes an increase in objectionable white tissue in interior fruit walls. Adults also transmit plant viruses. After feeding on infected plants, whiteflies can then transfer the virus to healthy plants. Unlike the mosaic viruses transmitted rapidly by aphids, the geminiviruses are transmitted persistently. It takes longer for the whitefly to acquire the virus and the virus must pass through the body of the insect into the salivary glands before the whitefly can transmit it to a healthy plant. The whitefly has to feed on a healthy plant for some time to cause infection. Once the whitefly acquires the virus, it may transmit it for the rest of its life. In addition to tomato mottle geminivirus, the very severe tomato yellow leaf curl virus has recently been introduced into Florida.

Silverleaf whitefly can reach high numbers on tomato and eggplant but is rarely a problem on peppers. Generally, whitefly populations are highest in South, Southwest and West Central Florida during the spring although, in West Central Florida, the number of whiteflies carrying virus is usually higher in the fall. The whitefly is less often a problem in North Florida but may reach damaging numbers in summer and fall. Tomato yellow leaf curl virus causes problems in all tomato-growing areas in Florida.

Table 1. Silverleaf Whitefly

\begin{tabular}{||l|l||}
\hline \hline $\begin{array}{c}\text { Management } \\
\text { Option }\end{array}$ & \multicolumn{1}{c||}{ Recommendation } \\
\hline $\begin{array}{l}\text { Scouting/ } \\
\text { thresholds }\end{array}$ & $\begin{array}{l}\text { For tomatoes, examine six feet of } \\
\text { row (a sample) for every 2.5 acres. } \\
\text { When plants have three or fewer } \\
\text { true leaves, examine six plants per } \\
\text { sample for adult whiteflies. If plants } \\
\text { have more than three leaves, } \\
\text { examine the terminal leaflet of the } \\
\text { third leaf from the top of the stalk. } \\
\text { For nymphs, examine a terminal } \\
\text { leaflet from the third leaf from the } \\
\text { top until seven leaves are present } \\
\text { and from the seventh leaf from the } \\
\text { top thereafter. Look at six leaflets } \\
\text { per six feet of row and calculate an } \\
\text { average per leaflet. Tentative } \\
\text { thresholds are 0.5 pupae or } \\
\text { nymphs per leaflet or 10 adults per } \\
\text { plant (0-3 true leaves) or 1 adult per } \\
\text { leaflet (over 3 true leaves). }\end{array}$ \\
\hline \hline
\end{tabular}


Table 1. Silverleaf Whitefly

\begin{tabular}{|c|c|}
\hline $\begin{array}{c}\text { Management } \\
\text { Option }\end{array}$ & Recommendation \\
\hline Note(s) & $\begin{array}{l}\text { Soil application of a systemic, } \\
\text { nicotinoid insecticide at crop } \\
\text { initiation controls whiteflies well and } \\
\text { reduces virus spread. To avoid the } \\
\text { development of resistance to this } \\
\text { insecticide, it is recommended that } \\
\text { applications be made to the earliest } \\
\text { "at risk" plantings using the } \\
\text { lowest labeled rate. Fields should } \\
\text { be scouted to determine the need } \\
\text { for additional applications, using a } \\
\text { different active ingredient, } \\
\text { preferably an insect growth } \\
\text { regulator or other selective } \\
\text { material. }\end{array}$ \\
\hline Mulches & $\begin{array}{l}\text { Reflective aluminum mulches may } \\
\text { reduce virus spread by deterring } \\
\text { adult whiteflies from landing on } \\
\text { plants. }\end{array}$ \\
\hline $\begin{array}{l}\text { Natural } \\
\text { enemies }\end{array}$ & $\begin{array}{l}\text { Parasitic wasps, lady beetles, } \\
\text { lacewings, minute pirate bugs, } \\
\text { fungi, particularly when whiteflies } \\
\text { are developing on weeds. }\end{array}$ \\
\hline $\begin{array}{l}\text { Cultural } \\
\text { controls }\end{array}$ & $\begin{array}{l}\text { Tomato is the major source of } \\
\text { whitefly-transmitted viruses, so } \\
\text { attention should be paid to the } \\
\text { probable source of whiteflies } \\
\text { invading a field, given that highest } \\
\text { risk is from senescing, abandoned } \\
\text { or 'volunteer' tomatoes. } \\
\text { A two-month or more crop-free } \\
\text { period will reduce virus and whitefly } \\
\text { populations. }\end{array}$ \\
\hline
\end{tabular}

\section{Aphids}

\section{Description and Biology}

Aphids (Figure 2) are soft-bodied, sucking insects that can rapidly colonize plants due to their short generation time. Adults are delicate, pear- or spindle-shaped insects with a posterior pair of tubes (cornicles), which project upward and backward from the dorsal surface of the abdomen and which are used for excreting a defensive fluid. In Florida, winged and wingless forms are all female and give birth to living young (nymphs). Nymphs are smaller but otherwise similar in appearance to wingless adults, which they become in 7 to 10 days.

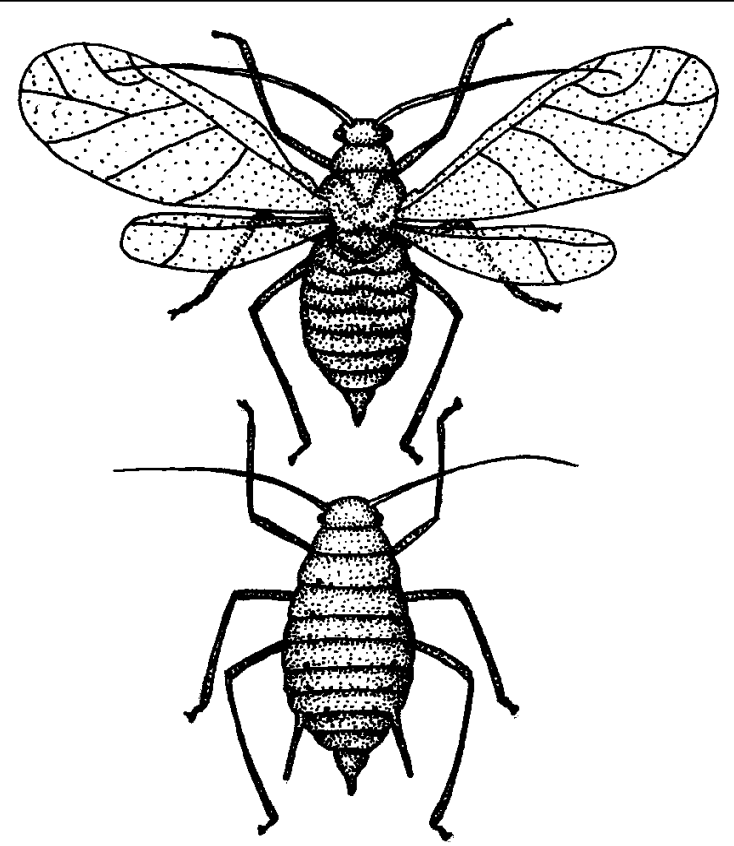

Figure 2. Winged aphid (top) and wingless aphid (bottom).

The green peach aphid, Myzus persicae, is the most common aphid species in Florida peppers and tomatoes, although the potato aphid (Macrosiphum euphorbiae) may also occur. Green peach aphid adults vary from 0.04 to 0.08 inch in length and are light green to yellow to pink and pear-shaped. The tubercles (bumps between antennae) point inward and are a distinguishing characteristic. Winged forms have a black patch on the back of the abdomen.

\section{Damage}

Heavy aphid infestations may cause stunting and leaf distortion. Feeding on blossoms reduces fruit set. Sooty mold will grow on the honeydew that the aphids excrete. They also spread plant viruses such as tobacco etch, potato virus $\mathrm{Y}$, and pepper mottle. Most transmission results from winged aphids probing the leaf surface, rejecting the plant as a host, flying to another plant, and probing again. Aphids that settle, feed, and reproduce on the plant are less likely to transmit virus. Aphids can acquire and transmit the virus in a matter of seconds (although they lose the virus after probing a few plants) so conventional insecticides are of no help in controlling the spread of these viruses. Sources of infection are nearby virus-infected tomato, pepper, tobacco or other host plants. Related weeds such as nightshade may also be infected and serve as a source of virus for the crop. 
Table 2. Aphids

\begin{tabular}{|c|c|}
\hline $\begin{array}{c}\text { Management } \\
\text { Option }\end{array}$ & Recommendation \\
\hline $\begin{array}{l}\text { Scouting/ } \\
\text { thresholds }\end{array}$ & $\begin{array}{l}\text { For tomatoes, examine six feet of } \\
\text { row (a sample) for every } 2.5 \text { acres. } \\
\text { When plants have two or fewer true } \\
\text { leaves, examine six plants per } \\
\text { sample for aphids. If plants have } \\
\text { more than three leaves but are not } \\
\text { yet blooming, examine the terminal } \\
\text { three leaflets (trifoliate) of the third } \\
\text { expanded leaf from the top of the } \\
\text { main stem. After bloom, examine } \\
\text { the terminal trifoliate of the seventh } \\
\text { leaf from the tip of any branch. } \\
\text { Look at six trifoliates per six feet of } \\
\text { row and calculate an average per } \\
\text { trifoliate. Treat with appropriate } \\
\text { insecticides if aphids reach } 3 \text { to } 4 \\
\text { per plant. }\end{array}$ \\
\hline Note(s) & $\begin{array}{l}\text { Insecticides will not slow the } \\
\text { spread of most aphid-transmitted } \\
\text { plant viruses. Certain mineral oil } \\
\text { formulations, if applied strictly } \\
\text { according to the label before } \\
5 \%-10 \% \text { infection, may delay } \\
\text { spread of these viruses by } \\
\text { interfering with the attachment of } \\
\text { virus to the aphid's mouthparts. }\end{array}$ \\
\hline Mulches & $\begin{array}{l}\text { Reflective aluminum mulches will } \\
\text { deter aphids from landing on plants. } \\
\text { The effect is lost once plants are } \\
\text { large enough to cover the mulch. }\end{array}$ \\
\hline $\begin{array}{l}\text { Natural } \\
\text { enemies }\end{array}$ & $\begin{array}{l}\text { Parasitic wasps, ladybird beetles, } \\
\text { syrphid fly larvae, and lacewing } \\
\text { larvae attack aphids that reproduce } \\
\text { on the crop. In humid weather, } \\
\text { fungi may kill many aphids. }\end{array}$ \\
\hline
\end{tabular}

\section{True Bugs (Hemiptera)}

\section{Description}

Like aphids and whiteflies, true bugs are sucking insects. True bugs can be recognized by their front wings, which are leathery close to the body but membrane-like at the tips. Nymphs resemble adults in shape but are often colored differently and do not have fully developed wings. Stink bugs (Pentatomidae) (Figure 3) are green or brown shield-shaped bugs $1 / 2$ to $2 / 3$ of an inch long. Eggs are barrel-shaped and found on the undersides of leaves in masses of 10 to 50 . Nymphs are similar in shape to adults, but more brightly colored and patterned. Leaffooted bugs (Coreidae) (Figure 4) are dark-colored true bugs with parallel sides. Three species attack tomato in Florida, two of which have flattened hind tibia (lower legs). Eggs are metallic and ovate but somewhat flattened laterally and laid in clusters. Some leaffooted bugs lay their eggs end to end in a single row or chain along a stem or leaf midrib. Nymphs are oblong in shape and red, especially on the abdomen.

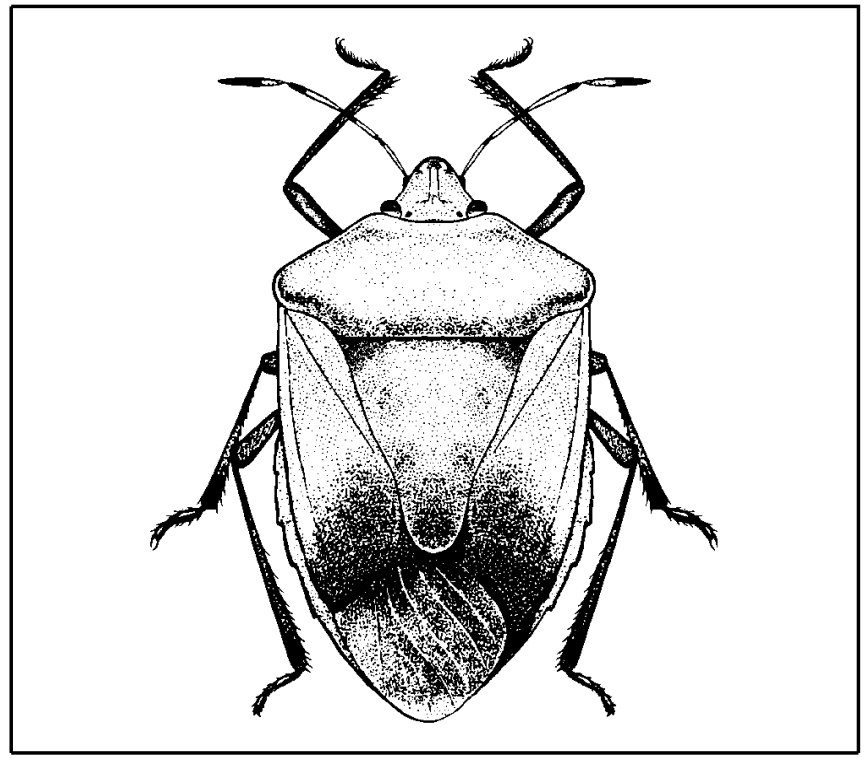

Figure 3. Green stink bug.

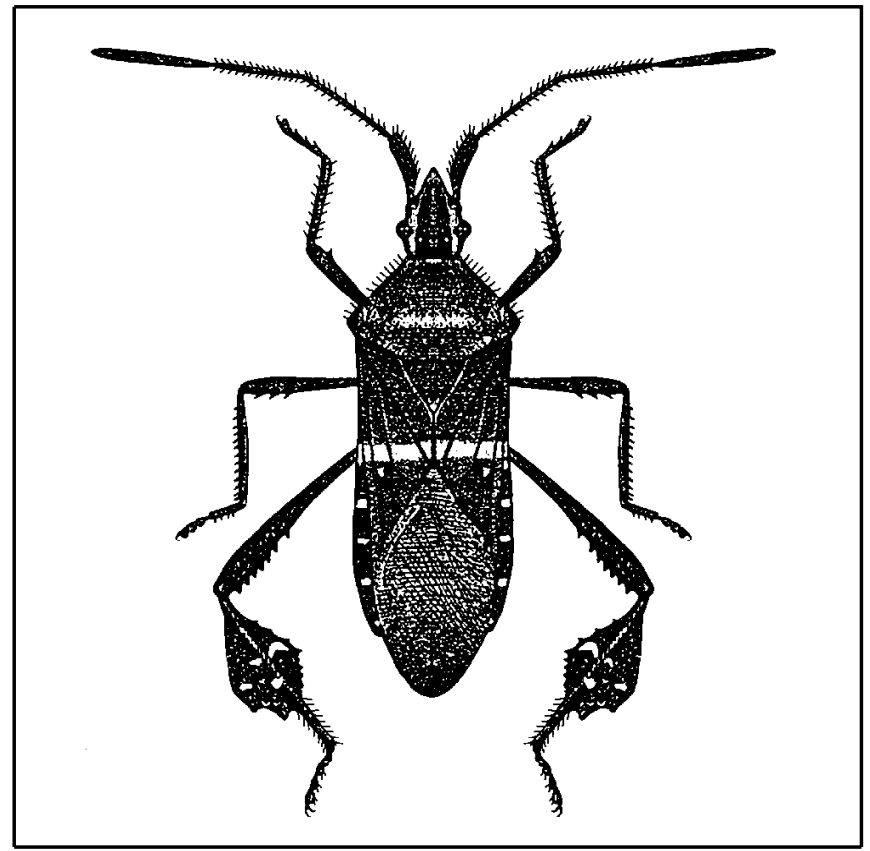

Figure 4. Leaffooted plant bug. 


\section{Biology}

Southern green stinkbug can complete its life cycle in 65 to 70 days. It overwinters as an adult in leaf litter, tree bark, and other protected sites. Weed hosts include beggarweed, rattlebox, Mexican clover, wild blackberry, and nutgrass. Leaffooted bugs also attack a wide variety of plants, although thistles and nightshade are principal hosts. Both stink bugs and leaffooted bugs emit a strong odor when disturbed.

\section{Damage}

Nymphs and adults of both stink bugs and leaffooted bugs suck juices from green fruit leaving a puncture which later may become surrounded by a discolored zone due to invasion of secondary pathogens. Stink bug feeding punctures are often surrounded with a lightened, sometimes depressed, blotch beneath the fruit surface caused by the removal of cell contents and the enzymes injected by the bug. Leaffooted punctures may cause fruit to become distorted as they enlarge. True bugs are occasional pests throughout Florida.

Table 3. True Bugs

\begin{tabular}{||l|l||}
\hline \hline $\begin{array}{c}\text { Management } \\
\text { Option }\end{array}$ & \multicolumn{1}{c||}{ Recommendation } \\
\hline $\begin{array}{l}\text { Scouting/ } \\
\text { thresholds }\end{array}$ & $\begin{array}{l}\text { After fruit set, examine 10 fruit per } \\
\text { 6-foot section of row for each 2.5 } \\
\text { acres. If there is more than one } \\
\text { stink bug per six plants, apply } \\
\text { insecticide. }\end{array}$ \\
\hline Natural & $\begin{array}{l}\text { Several species of parasitoid wasps } \\
\text { attack eggs of leaffooted bugs. } \\
\text { Insect predators also consume } \\
\text { eggs. A tachinid fly parasitizes stink } \\
\text { bug nymphs and adults, and a wasp } \\
\text { parasitizes eggs. }\end{array}$ \\
\hline Cultural \\
controls & $\begin{array}{l}\text { Trap crops (cowpeas and beans in } \\
\text { summer, cruciferous plants in early } \\
\text { spring and fall) may have some } \\
\text { value. The trap crop should be } \\
\text { sprayed before stink bug nymphs } \\
\text { become adults. Weed } \\
\text { management in and around the field } \\
\text { prior to planting the crop is } \\
\text { important. }\end{array}$ \\
\hline \hline
\end{tabular}

\section{Western Flower Thrips, Frankliniella occidentalis}

\section{Description and Biology}

Adults (Figure 5) are tiny (1/16 inch) slender, dark yellow insects with brown, fringed wings. They are most often located in flowers, but also occur in terminal buds and, occasionally, on leaves. The egg is inserted in plant tissue, especially flower parts and very small fruit. Larvae, which are small, yellow and wingless, inhabit primarily flowers but also terminal buds and leaves. A prepupal stage resembling the larva does not feed but falls to the ground and pupates in the soil. Thrips can complete their life cycle in 15 to 30 days depending on temperature.

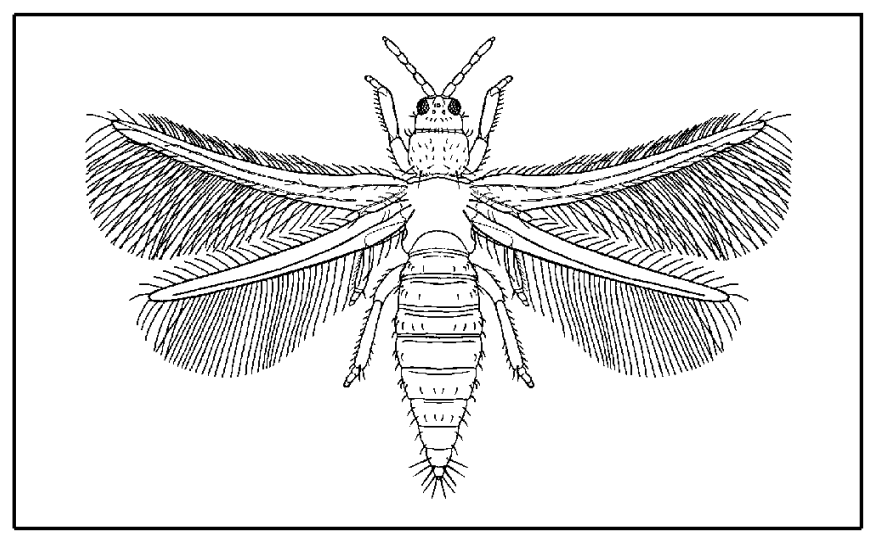

Figure 5. Western flower thrip.

\section{Damage}

Eggs inserted individually in tomato fruit cause dimples, sometimes surrounded by a white area, especially on the blossom end of the fruit. Heavy dimpling results in cullout and downgrading. The western flower thrips is a vector of tomato spotted wilt virus and is a key pest in north Florida during the spring but is rarely a pest in the fall. Although the western flower thrips has not been a pest of field tomatoes in South Florida, tomato spotted wilt virus has occurred sporadically but at low incidence. 
Table 4. Western Flower Thrips

\begin{tabular}{||l|l||}
\hline \multicolumn{1}{|c|}{$\begin{array}{c}\text { Management } \\
\text { Option }\end{array}$} & \multicolumn{1}{c|}{ Recommentation } \\
\hline $\begin{array}{l}\text { Scouting/ } \\
\text { thresholds }\end{array}$ & $\begin{array}{l}\text { For tomatoes, examine one 6-foot } \\
\text { section of row for each 2.5 acres. } \\
\text { Gently exhale on each of 10 } \\
\text { flowers per 6-foot section and } \\
\text { count the number of thrips seen } \\
\text { coming out of the flower. Treat if } \\
\text { there are more than 5 thrips per } \\
\text { flower. }\end{array}$ \\
\hline $\begin{array}{l}\text { Natural } \\
\text { enemies }\end{array}$ & $\begin{array}{l}\text { Minute or insidious pirate bugs } \\
\text { feed on thrips, as does a certain } \\
\text { mite. }\end{array}$ \\
\hline $\begin{array}{l}\text { Cultural } \\
\text { practices }\end{array}$ & $\begin{array}{l}\text { Because western flower thrips } \\
\text { pupae occur in the soil, new } \\
\text { plantings of tomatoes, eggplants, } \\
\text { and peppers should not be planted } \\
\text { following, near or adjacent to old, } \\
\text { infested plantings. Reflective } \\
\text { aluminum mulches reduce spread } \\
\text { of tomato spotted wilt virus. }\end{array}$ \\
\hline \hline
\end{tabular}

\section{Melon Thrips, Thrips palmi}

\section{Description and Biology}

Adults (Figure 6) are tiny (about 1/25 inch long), slender, dark yellow insects with brown-lined wings. They may first appear in flowers but may also occur on foliage, especially on the undersides of young leaves. Many similar species inhabit flowers, so identification requires a microscope. The egg is inserted in plant tissue, especially flower parts and very small fruit. Larvae, which are yellow and small without wings, inhabit flowers, fruit (especially under the calyx), and foliage, congregating where veins converge. Such congregations clearly denote melon thrips. A prepupal stage resembling the larva does not feed but falls to the ground and pupates in the soil or in leaf litter. Generation type varies from 15 to 30 days, depending on temperature. Melon thrips have a broad host range and are a primary foliage pest on watermelon, eggplant, pepper, and cucumber. So far, melon thrips has been reported only south of Orlando.

\section{Damage}

Heavy infestations cause silvered or bronzed leaves, stunted leaves and terminals, and scarred and deformed fruit. On peppers, fruit scaring emanates from the stem end following crevices between locule lobes. Foliar damage may also be severe. Melon thrips also damages eggplant. Tomatoes are not affected.

Table 5. Melon Thrips

\begin{tabular}{||l|l||}
\hline \hline $\begin{array}{c}\text { Management } \\
\text { Option }\end{array}$ & \multicolumn{1}{c||}{ Recommendation } \\
\hline $\begin{array}{l}\text { Scouting/ } \\
\text { Thresholds }\end{array}$ & No guidelines available. \\
\hline Note(s) & $\begin{array}{l}\text { Most conventional insecticides } \\
\text { seem to stimulate melon thrips } \\
\text { populations, possibly by eliminating } \\
\text { predators that otherwise control } \\
\text { them. Therefore, broad-spectrum } \\
\text { insecticides should be avoided as } \\
\text { much as possible in preference to } \\
\text { selective materials when available. }\end{array}$ \\
\hline Natural & $\begin{array}{l}\text { Pirate bugs (Orius spp.), several } \\
\text { species of predacious mites and } \\
\text { predacious thrips, and a parasitoid } \\
\text { wasp. }\end{array}$ \\
\hline Mulches & $\begin{array}{l}\text { Adults are quite mobile and can } \\
\text { move into new plantings quickly } \\
\text { from old fields. Therefore, old fields } \\
\text { should be destroyed as soon as } \\
\text { possible after the last harvest and } \\
\text { new fields should not be planted } \\
\text { adjacent to or near old fields. In } \\
\text { addition to infesting pepper and } \\
\text { eggplant, melon thrips can easily } \\
\text { increase on successive plantings of } \\
\text { cucumber, potato, beans, and } \\
\text { watermelon, which are also hosts } \\
\text { of this pest. Tomato, which is not } \\
\text { susceptible, can be used to } \\
\text { separate such crops in time and } \\
\text { space. }\end{array}$ \\
\hline controls & $\begin{array}{l}\text { Reflective mulches give some } \\
\text { control when plants are small. }\end{array}$ \\
\hline
\end{tabular}

\section{Tobacco Thrips, Frankliniella fusca}

\section{Description}

Adults (Figure 7) are dark brown or black and thereby easily distinguished from the western flower thrips. There are other dark thrips, however, so identification by an expert is advisable. It is an occasional inhabitant of flowers, terminal buds, and leaves. The tobacco thrips also vectors tomato spotted wilt virus. Although tomato is not a preferred host, 
viruliferous adults may migrate into fields from tobacco or peanut, especially in the fall, and transmit tomato spotted wilt virus to tomatoes and peppers by probing with their mouthparts. Therefore, tomatoes and peppers should not be planted adjacent to or near these tomato spotted wilt virus-susceptible crops.

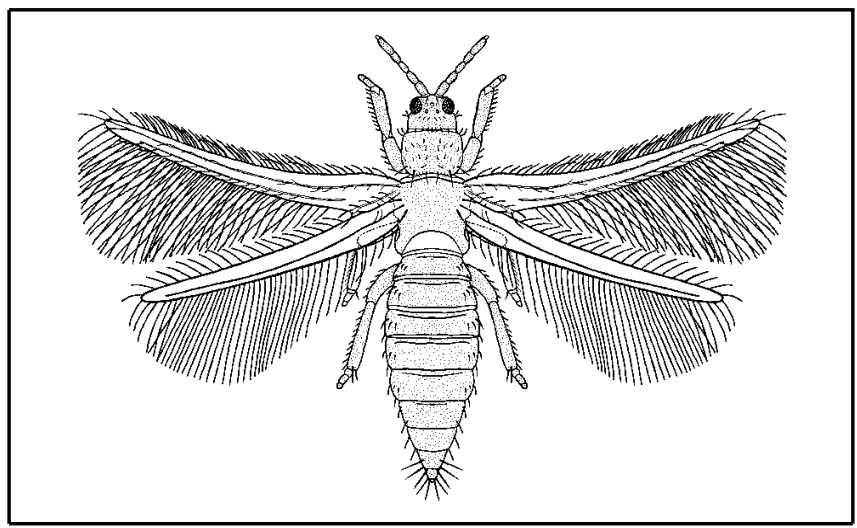

Figure 7. Tobacco thrip.

\section{Other Thrips}

Eastern flower thrips (F. tritici) and the Florida flower thrips ( $F$. bispinosa) are some common thrips that resemble western flower thrips and may be numerous in blooms. Eastern flower thrips is most abundant in north Florida but is not a pest of tomato. Florida flower thrips is common throughout the state and may cause bud abscission if present in very high numbers ( $>5$ per flower). Experimentally, it has been shown to be a vector of tomato spotted wilt virus but its potential as a vector in nature has not been determined.

\section{Vegetable Leafminer, Liriomyza sativae, L. trifolii}

\section{Description and Biology}

The adult is a small fly (Figure 8), approximately $1 / 8$ inch long, with a black head, yellow between the eyes, a black thorax and a tube-like "ovipositor" at the end of the abdomen used to puncture the upper leaf surface for egg laying. The white, oval egg is inserted in the leaf tissue, but many punctures (called stipples) are used by the adult for feeding and do not contain eggs. The larva, a yellow maggot with black, sickle-shaped mouth hooks, feeds between the upper and lower leaf surface for approximately seven days, leaving a serpentine mine containing a string of black frass (fecal matter). The mature larva exits from the mine and falls to the ground (or plastic mulch) where it molts to a pupa within a golden brown, barrel-shaped and ribbed, puparium from which the adult emerges in seven to 14 days. Generation time is 15 to 28 days depending upon temperature.

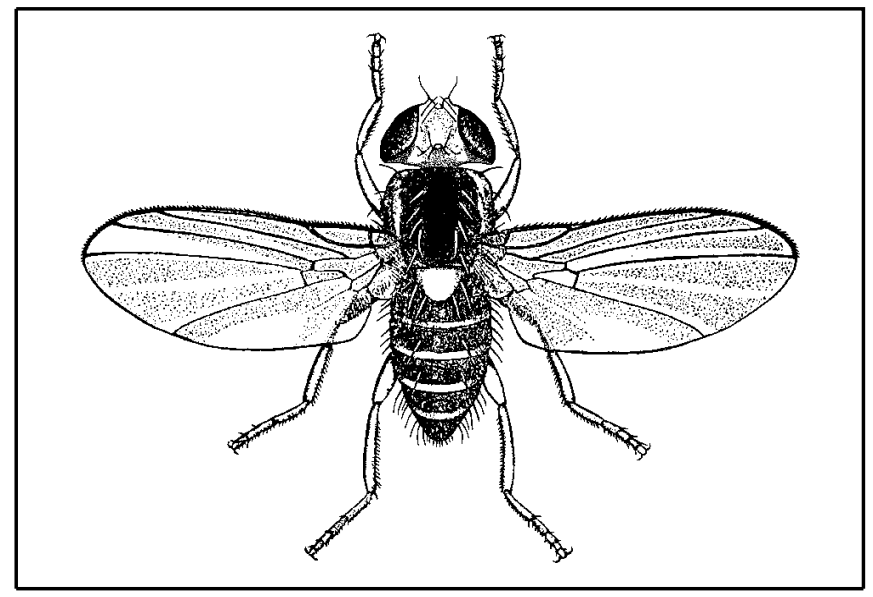

Figure 8. Vegetable leafminer.

\section{Damage}

Leafmines reduce photosynthetic area and may provide entry points for foliar pathogens. Heavily damaged leaves become necrotic, predisposing fruit to sunscald. Vegetable leafminer may be an important pest in south and central Florida but is only an occasional pest in north Florida. It is not usually a serious pest of pepper or eggplant. 
Table 6. Vegetable Leafminer

\begin{tabular}{|c|c|}
\hline $\begin{array}{c}\text { Management } \\
\text { Option }\end{array}$ & Recommendation \\
\hline $\begin{array}{l}\text { Scouting/ } \\
\text { Thresholds }\end{array}$ & $\begin{array}{l}\text { For tomatoes, examine six feet of } \\
\text { row (a sample) for every } 2.5 \text { acres. } \\
\text { When plants have two or fewer true } \\
\text { leaves, examine six plants per } \\
\text { sample for leafminers. If plants } \\
\text { have three to seven leaves, } \\
\text { examine the terminal three leaflets } \\
\text { (trifoliate) of the third expanded } \\
\text { leaf from the top of the main stem. } \\
\text { After seven leaves are present, } \\
\text { examine the terminal trifoliate of } \\
\text { the seventh leaf from the tip of any } \\
\text { branch. Look at six trifoliates per } \\
\text { six feet of row and calculate an } \\
\text { average per trifoliate. Treat with } \\
\text { appropriate insecticides if the } \\
\text { average is } 0.7 \text { larvae per plant (0-2 } \\
\text { true leaves) or } 0.7 \text { larvae per } 3 \\
\text { terminal leaflets (>2 leaves per } \\
\text { plant). }\end{array}$ \\
\hline Note(s) & $\begin{array}{l}\text { Insecticides applied for leafminer } \\
\text { control should target small larvae } \\
\text { for best results. }\end{array}$ \\
\hline $\begin{array}{l}\text { Natural } \\
\text { enemies }\end{array}$ & $\begin{array}{l}\text { A number of parasitic wasps attack } \\
\text { vegetable leafminer in Florida and } \\
\text { may provide high levels of } \\
\text { mortality, especially late in the } \\
\text { season. Therefore, insecticides } \\
\text { with low or no toxicity to leafminer } \\
\text { parasites should be selected for } \\
\text { controlling leafminers and other } \\
\text { pests. }\end{array}$ \\
\hline
\end{tabular}

\section{Tomato Pinworm, Keiferia lycopersicella}

\section{Description}

The adult is a small gray moth (wing span about $1 / 2$ inch) with a reddish-brown, mottled head and thorax. Eggs are pale yellow to orange, oval in shape, and are usually deposited singly or in groups of two to three on lower surfaces of foliage. Larvae (Figure 9) are purplish-gray, $3 / 8$ inch long at maturity, and found inside blotch mines, leaf folds or fruit, usually around the stem attachment. The pupa is formed in a silken cocoon covered with sand particles near the soil surface or on the plastic mulch surface.

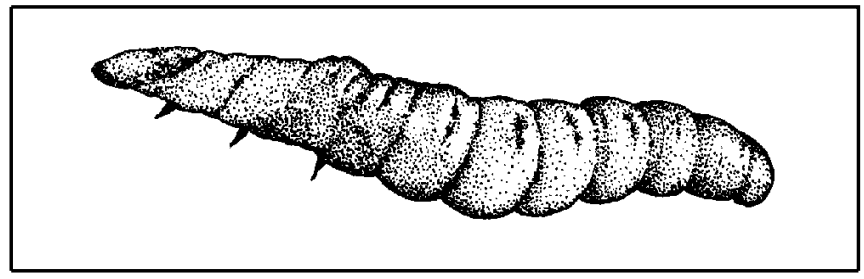

Figure 9. Tomato pinworm larva.

\section{Biology}

Moths are most active at dusk. The female emits an odor, or pheromone, which attracts males from long distances downwind for mating. After hatching, first instars spin silk over themselves and tunnel into the leaf. Third and fourth stages fold or tie leaves or feed in stems or fruit. The pupal stage can last 1 to 4 weeks. Total generation time varies from 21 to 67 days depending on temperature. Seven to eight overlapping generations a year occur in South Florida.

\section{Damage}

The tomato pinworm feeds only on solanaceous plants such as tomato, eggplant, and potato. Pepper is not a host. Heavy feeding on foliage may cause defoliation, but damage to fruit is usually the worst consequence of tomato pinworm infestations. Damaged fruits are contaminated with insect parts, silk and frass, and may rot from introduction of pathogens. The tomato pinworm is an important pest in the spring in south and central Florida and summer or late fall in North Florida, especially after populations have built up over the preceding season.

Table 7. Tomato Pinworm

\begin{tabular}{||l|l||}
\hline \hline $\begin{array}{c}\text { Management } \\
\text { Option }\end{array}$ & \multicolumn{1}{c||}{ Recommendation } \\
\hline Thresholds & $\begin{array}{l}\text { Count the number of larvae on the } \\
\text { foliage of whole plants (up to } 7^{\text {th }} \\
\text { true leaf stage), or on one leaf } \\
\text { selected from the lower canopy of } \\
\text { each plants (from 8 }{ }^{\text {th }} \text { true leaf to } \\
\text { end of crop). Treat if the following } \\
\text { thresholds are reached: 0.7 larva } \\
\text { per plant (0-7 leaves), 0.7 larva per } \\
\text { leaf (>7 true leaves). Also treat with } \\
\text { pheromone for mating disruption if } \\
5 \text { or more moths are caught per } \\
\text { night in a pheromone trap. }\end{array}$ \\
\hline \hline
\end{tabular}


Table 7. Tomato Pinworm

\begin{tabular}{||l|l||}
\hline \hline $\begin{array}{c}\text { Management } \\
\text { Option }\end{array}$ & \multicolumn{1}{c||}{ Recommendation } \\
\hline Note(s) & $\begin{array}{l}\text { Mating disruption by application of } \\
\text { commercially available pheromone } \\
\text { preparations is preferred over } \\
\text { insecticidal control in order to } \\
\text { conserve parasites and predators } \\
\text { of tomato pinworm. }\end{array}$ \\
\hline Cultural & $\begin{array}{l}\text { Use clean transplants, separate } \\
\text { plantings from previous crops of } \\
\text { tomato, eggplant, or potato. Field } \\
\text { sanitation and destruction of crop } \\
\text { residue from previous plantings is } \\
\text { important for reducing summer } \\
\text { populations. }\end{array}$ \\
\hline \hline
\end{tabular}

\section{Tomato Fruitworm (corn earworm), Heliocoverpa zea}

\section{Description}

The wingspan is about 1.5 inches. The forewing of the adult male is cream-colored with an orange or olive cast; the females is light yellow-brown with indistinct vertical lines. Eggs are waxy, white, dome-shaped and ribbed, with a flat base. They are deposited singly on the undersides of leaves or flower petals. Larvae (Figure 10) can vary in color from light green or pink to brown or nearly black and are lighter underneath. The body is marked with lengthwise alternating light and dark stripes. Spines have raised dark areas at their bases.

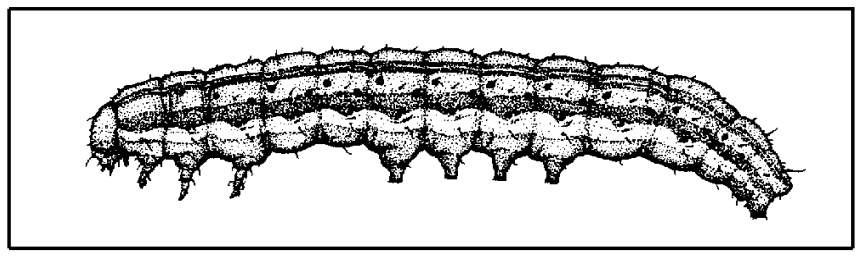

Figure 10. Tomato fruitworm (corn earworm) larva.

\section{Biology}

Adults are active at night. Eggs hatch in 2 or 3 days and the larval stage lasts $14-21$ days. Larvae move to green fruit soon after hatching, where they bore deeply into the fruit. Tomato fruitworm pupates in the soil; the adult emerges in 7 to 14 days.

\section{Damage}

Larvae chew large deep holes in tomato fruit, especially at the stem end. They occasionally feed on foliage. Eggplant and pepper fruits may also be damaged by tomato fruitworm.

Table 8. Tomato Fruitworm (corn earworm)

\begin{tabular}{||l|l||}
\hline $\begin{array}{c}\text { Management } \\
\text { Option }\end{array}$ & \multicolumn{1}{c||}{ Recommendation } \\
\hline $\begin{array}{l}\text { Scouting/ } \\
\text { Thresholds }\end{array}$ & $\begin{array}{l}\text { Examine } 6 \text { feet of row for every 2.5 } \\
\text { acres. Concentrate on areas where } \\
\text { there is evidence of feeding } \\
\text { (leaves, fruit). Examine the } \\
\text { undersides of leaves adjacent to } \\
\text { flowers for eggs. Treat if there is } \\
\text { one larva or more per six plants } \\
\text { before bloom; after bloom, treat if } \\
\text { one egg or larva is found per field. } \\
\text { Pheromone traps, placed on the } \\
\text { edge of the field, have been useful } \\
\text { for monitoring purposes in the } \\
\text { Midwest. }\end{array}$ \\
\hline Note(s) & $\begin{array}{l}\text { Insecticides must be present on } \\
\text { plants when eggs hatch so that } \\
\text { newly hatched larvae will contact a } \\
\text { lethal dose. }\end{array}$ \\
\hline Natural & $\begin{array}{l}\text { General predators, such as } \\
\text { big-eyed bugs and pirate bugs, } \\
\text { feed on eggs. Parasitoid wasps } \\
\text { attack eggs and larvae. }\end{array}$ \\
\hline \hline
\end{tabular}

\section{Southern Armyworm, Spodoptera eridania}

\section{Description}

The adult is relatively large (1.5 - inch wingspan) with the front wing streaked with cream, gray, light brown and black and the hindwing white with some dark on the margins. Eggs are laid on the undersides of leaves in large masses of 100 to 200, covered with a felt-like mat of body hair, which hatch in about three to four days. Larvae are dark caterpillars, two yellowish lateral lines interrupted by a large dark spot on the first abdominal segment (Figure 11). Large larvae have two rows of dark triangles on the dorsal surface. The generation time is 29 to 35 days. Southern armyworm is the most common armyworm pest of tomato in south and central Florida but is only an occasional pest in north Florida. 


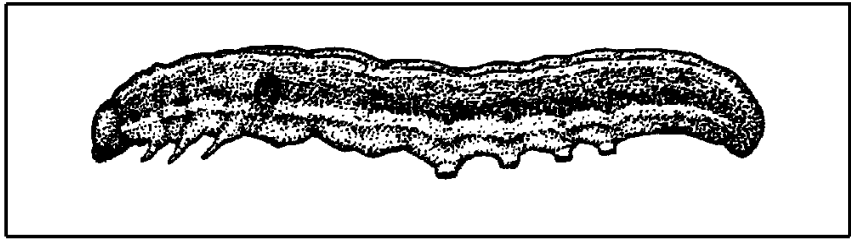

Figure 11. Southern armyworm larva.

\section{Beet Armyworm, Spodoptera exigua}

\section{Description}

The adult is smaller than southern armyworm, (wingspan one inch) with the front wing light brownish gray with indistinct lines and the hindwing white. Egg masses are also smaller than southern armyworm, numbering usually 50 to 75 eggs but are otherwise similar. Larvae (Figure 12) are generally green, mottled with white spots, one to $11 / 4$ inch long at maturity and often with a small black spot above the second pair of true legs. Generation time 25 to 35 days. Tomato is not a preferred host for beet armyworm but the insect may occasionally reach damaging levels anywhere in the state. Pepper is a preferred host, and larvae may feed on buds, silk leaves together, or may bore into fruit. The beet armyworm is more difficult to control than the southern armyworm.

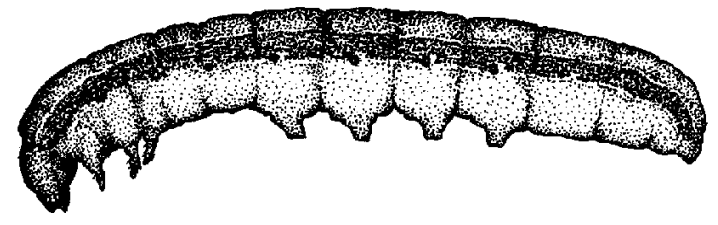

Figure 12. Beet armyworm larva.

\section{Yellowstriped Armyworm, Spodoptera ornithogalli \\ Description}

The adults and eggs are similar to the southern armyworm. Yellowstriped armyworm larvae (Figure 13) have dark heads and dark lateral marks bisected by a thin, white line on each segment behind the true legs. The yellowstriped armyworm is a serious pest in north Florida during the fall but is rarely present in south and central Florida.

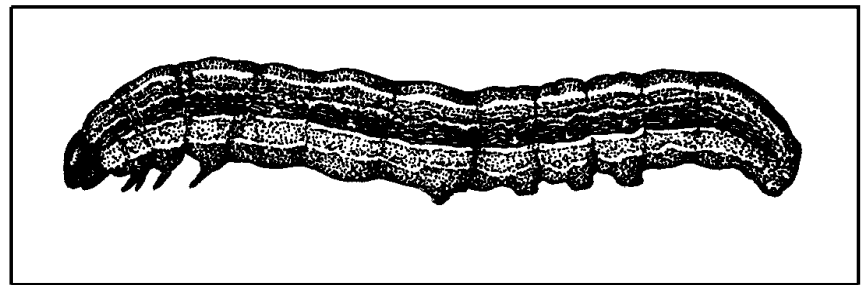

Figure 13. Yellowstriped armyworm larva.

Table 9. Management of Beet, Southern, Fall and Yellowstriped Armyworms

\begin{tabular}{||l|l||}
\hline \hline $\begin{array}{c}\text { Management } \\
\text { Option }\end{array}$ & \multicolumn{1}{c||}{ Recommendation } \\
\hline $\begin{array}{l}\text { Scouting/ } \\
\text { Thresholds }\end{array}$ & $\begin{array}{l}\text { Examine 6 feet of row for every 2.5 } \\
\text { acres. Concentrate on areas } \\
\text { where there is evidence of feeding } \\
\text { (leaves, fruit). Treat if there is one } \\
\text { larva or more per six plants before } \\
\text { bloom; after bloom, treat if one egg } \\
\text { or larva is found per field. }\end{array}$ \\
\hline Note(s) & $\begin{array}{l}\text { Younger larvae are always easier } \\
\text { to control than older larvae, } \\
\text { especially when using Bacillus } \\
\text { thuringiensis (Bt) products. }\end{array}$ \\
\hline Natural \\
enemies & $\begin{array}{l}\text { Many natural enemies attack } \\
\text { armyworms, including parasitoid } \\
\text { wasps and tachinid flies. General } \\
\text { predators feed on eggs and small } \\
\text { larvae. }\end{array}$ \\
\hline \hline
\end{tabular}

\section{Pepper Weevil, Anthonomus eugenii Description}

The adult (Figure 14) is a small (1/6 inch) black or gray beetle with a long snout (proboscis) and elbowed antennae. Larvae are tiny, legless grubs, found inside the pepper fruit.

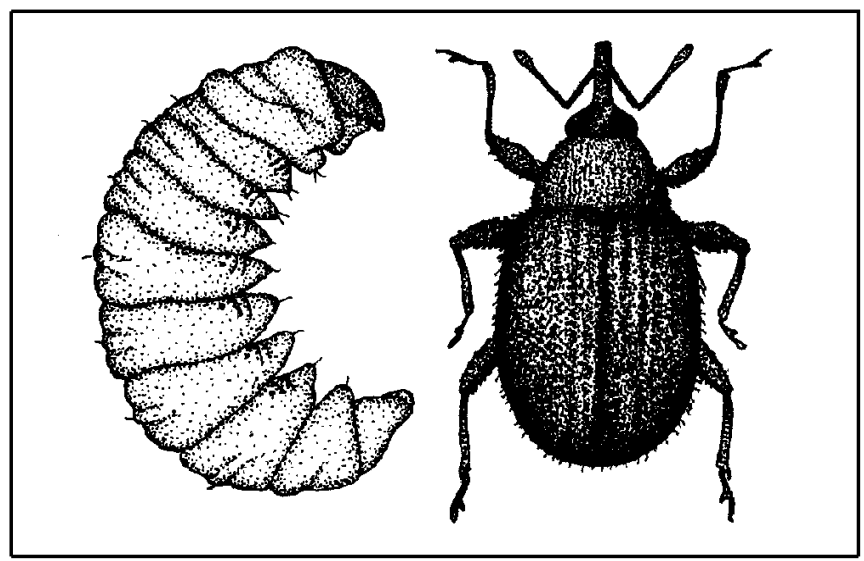

Figure 14. Pepper weevil larva and adult. 


\section{Biology}

Adults use the mandibles at the end of the proboscis to feed on leaf or flower buds. Females also use the mandibles to bore a small hole in developing fruit or flower buds. The hole is plugged with fecal matter (frass) after an egg is deposited. A tiny legless grub hatches from the egg and eats its way toward the seed core of the fruit where it feeds on seeds and pulp, passing through larval growth stages or instars. Pupation takes place inside the fruit within a small cell created by larval feeding. The emerging adult may feed within the fruit for awhile before escaping through a circular hole chewed in the wall of the fruit.

Black nightshade can serve as a secondary host to maintain small numbers of pepper weevil during fallow periods. Since development times decrease as temperature increases and since adults will migrate readily from old fields to new plantings, populations generally build up during the season so that populations are greatest in later spring plantings.

\section{Damage}

Damaged fruit become contaminated by insect parts, frass and rotted tissue, and will eventually fall from the plant.

Table 10. Pepper Weevil

\begin{tabular}{||l|l||}
\hline $\begin{array}{c}\text { Management } \\
\text { Option }\end{array}$ & \multicolumn{1}{c||}{ Recommendation } \\
\hline $\begin{array}{l}\text { Scouting/ } \\
\text { Thresholds }\end{array}$ & $\begin{array}{l}\text { Since adults tend to move to lower, } \\
\text { more protected and less visible } \\
\text { plant parts as temperatures } \\
\text { increase, scouting efforts should } \\
\text { concentrate on a search for adults } \\
\text { in leaf whorls, flowers, and fruit } \\
\text { during morning hours. } \\
\text { Commercially available pheromone } \\
\text { traps may also aid in early } \\
\text { detection. Fruit and flower buds } \\
\text { should be examined for damage } \\
\text { and fallen fruit and buds examined } \\
\text { for presence of larvae. }\end{array}$ \\
\hline \hline
\end{tabular}

Table 10. Pepper Weevil

\begin{tabular}{||l|l||}
\hline \hline \multicolumn{1}{|c|}{$\begin{array}{c}\text { Management } \\
\text { Option }\end{array}$} & \multicolumn{1}{c|}{ Recommendation } \\
\hline Note(s) & $\begin{array}{l}\text { Chemical control is difficult because } \\
\text { all stages except the adult are } \\
\text { protected within the fruit, so that } \\
\text { only the adult weevil is vulnerable } \\
\text { to insecticides. Frequent sprays } \\
\text { may be necessary starting in the } \\
\text { initial stages of infestation, usually } \\
\text { pre-bloom, in order to avoid } \\
\text { unacceptable levels of damage. }\end{array}$ \\
\hline Natural & $\begin{array}{l}\text { A few parasites and predators are } \\
\text { known to attack the weevil, but are } \\
\text { not thought to be a factor in } \\
\text { suppressing populations. }\end{array}$ \\
\hline $\begin{array}{l}\text { Cultural } \\
\text { controls }\end{array}$ & $\begin{array}{l}\text { If possible, all damaged and fallen } \\
\text { fruit should be removed and } \\
\text { destroyed. Adjacent or nearby } \\
\text { sequential plantings should be } \\
\text { avoided. Crops should be } \\
\text { deep-plowed immediately following } \\
\text { harvest and after treating with } \\
\text { insecticide to reduce adult } \\
\text { movement into nearby fields and to } \\
\text { reduce survival over the summer. } \\
\text { Nightshade in and around fields } \\
\text { should be controlled to reduce } \\
\text { population survival between crops. }\end{array}$ \\
\hline \hline
\end{tabular}

\section{Broad Mite, Polyphagotarsonemus latus}

\section{Description and Biology}

Adults (Figure 15) are tiny, white, eight-legged mites and are usually most numerous on the underside of young, emergent foliage. Males can sometimes be seen carrying females "piggyback." Nymphs are similar though somewhat smaller than adults are. Eggs are about 1/4 the size of adults, round with white, opalescent spots, and glued to the plant surface. Generation time may be as short as 5 days, depending on temperature.

\section{Damage}

In peppers, broad mite feeding distorts plant tissue, causing leaves to become thickened and narrow, giving them a "strappy" appearance. Heavy feeding causes flower abortion and dark, smooth 


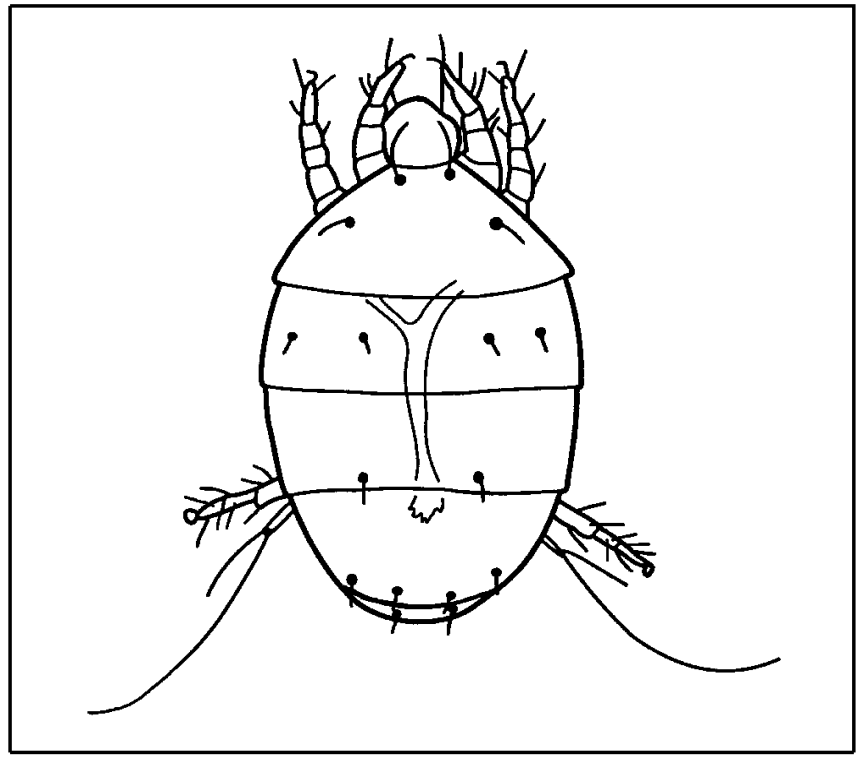

Figure 15. Broad mite.

russeting of fruit. Infestations are often spotty, but may become more generalized, especially in late fall. Broad mite is a major pest of pepper and eggplant.

Table 11. Broad Mite

\begin{tabular}{||l|l||}
\hline \hline $\begin{array}{l}\text { Management } \\
\text { Option }\end{array}$ & \multicolumn{1}{c||}{ Recommendation } \\
\hline $\begin{array}{l}\text { Scouting/ } \\
\text { Thresholds }\end{array}$ & $\begin{array}{l}\text { None currently available for } \\
\text { Florida. Infestations occurring } \\
\text { during at or before the early fruiting } \\
\text { stage of peppers cause the most } \\
\text { damage. }\end{array}$ \\
\hline Note(s) & $\begin{array}{l}\text { Chemical control is not difficult but } \\
\text { should be timely. Heavy infestation } \\
\text { may require two applications five } \\
\text { days apart to allow time for eggs to } \\
\text { hatch. Specific acaricides are } \\
\text { usually recommended over } \\
\text { broad-spectrum } \\
\text { acaricide/insecticides to better } \\
\text { conserve beneficial insects. }\end{array}$ \\
\hline $\begin{array}{l}\text { Natural } \\
\text { enemies }\end{array}$ & $\begin{array}{l}\text { General mite predators can be } \\
\text { effective. }\end{array}$ \\
\hline \hline
\end{tabular}

\section{Colorado Potato Beetle, Leptinotarsa decemlineata}

\section{Description}

Adults (Figure 16) have 10 lengthwise black stripes on yellow-orange wing covers and are approximately $3 / 8$ inch long by $1 / 4$ inch wide. They are distinctly convex in shape. Clusters of 10 or more yellow to orange spindle-shaped eggs can be found on the undersides of leaves. The larvae are humpbacked, red to orange, and have two rows of black spots on each side of their soft bodies.

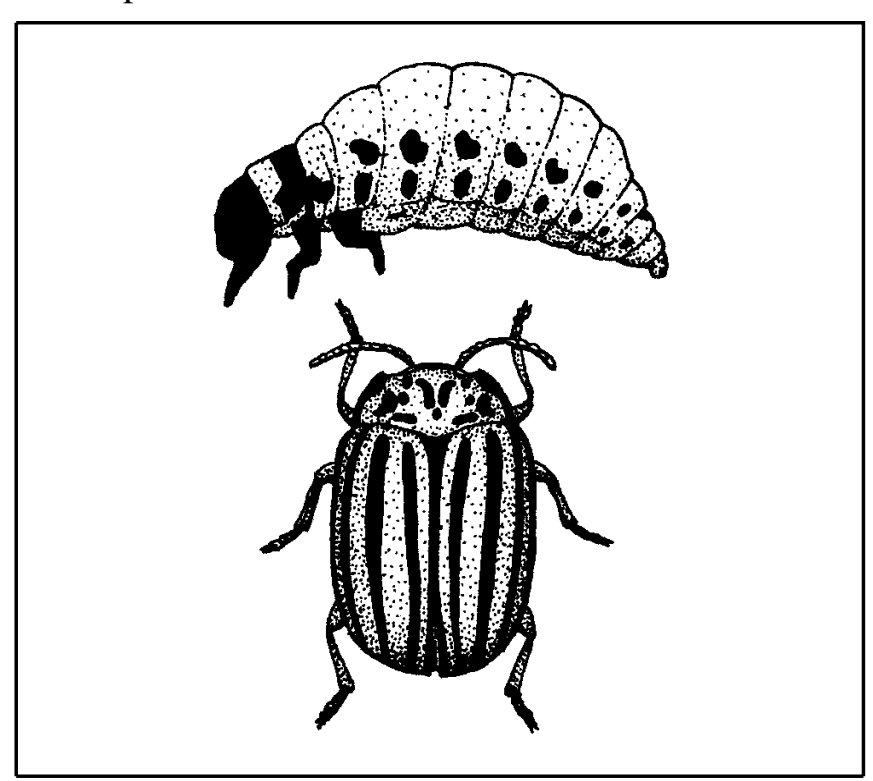

Figure 16. Colorado potato beetle larva and adult.

\section{Biology}

Colorado potato beetle is primarily a pest in the northern half of the state. Adults will overwinter in debris around the edges of fields planted the previous season with potatoes, eggplant, or tomatoes. In the spring, they lay eggs in clusters of $10-40$ that will hatch in 3 to 7 days, depending on temperature. Females may deposit over 300 eggs over a 4 to 5 -week period. Larvae complete 4 instars while feeding on leaves for two to three weeks and drop to the soil to pupate. New adults emerge from the soil 5 to 10 days later, or longer, depending on temperature. Colorado potato beetle attacks primarily potatoes, eggplant, and tomatoes, but it will also feed on peppers, tobacco, and solanaceous weeds, such as nightshade, horse-nettle, and ground cherry. 


\section{Damage}

They are voracious leaf feeders and will totally defoliate plants.

Table 12. Colorado Potato Beetle

\begin{tabular}{||l|l||}
\hline \hline $\begin{array}{l}\text { Management } \\
\text { Option }\end{array}$ & \multicolumn{1}{c|}{ Recommendation } \\
\hline $\begin{array}{l}\text { Scouting/ } \\
\text { Thresholds }\end{array}$ & $\begin{array}{l}\text { There are no thresholds for } \\
\text { Florida. Other states recommend } \\
\text { examining at least 30 plants per } \\
\text { field and treating if more than 1 } \\
\text { adult, larva, or egg mass per plant } \\
\text { is found (average of 30 plants). }\end{array}$ \\
\hline Note(s) & $\begin{array}{l}\text { Insecticide resistance is a major } \\
\text { problem in other parts of the } \\
\text { country. }\end{array}$ \\
\hline Natural \\
enemies & $\begin{array}{l}\text { Good results have been obtained } \\
\text { with a tiny wasp that parasitizes } \\
\text { eggs. The wasp, Edovum puttleri, } \\
\text { was introduced from South } \\
\text { America and mass-reared for } \\
\text { release in the Northeast. }\end{array}$ \\
\hline $\begin{array}{l}\text { Cultural } \\
\text { practices }\end{array}$ & $\begin{array}{l}\text { Rotation with non-host plants, } \\
\text { such as corn, is effective, because } \\
\text { beetles are weak fliers. Plant at } \\
\text { least 1/2 mile away from a } \\
\text { previously infested field. Potatoes } \\
\text { can be used as a trap crop for } \\
\text { tomatoes. One or two rows of } \\
\text { potatoes planted 20 to 30 days } \\
\text { before tomatoes will attract adult } \\
\text { beetles, which can then be killed } \\
\text { with insecticides before they move } \\
\text { into the tomatoes. }\end{array}$ \\
\hline \hline
\end{tabular}




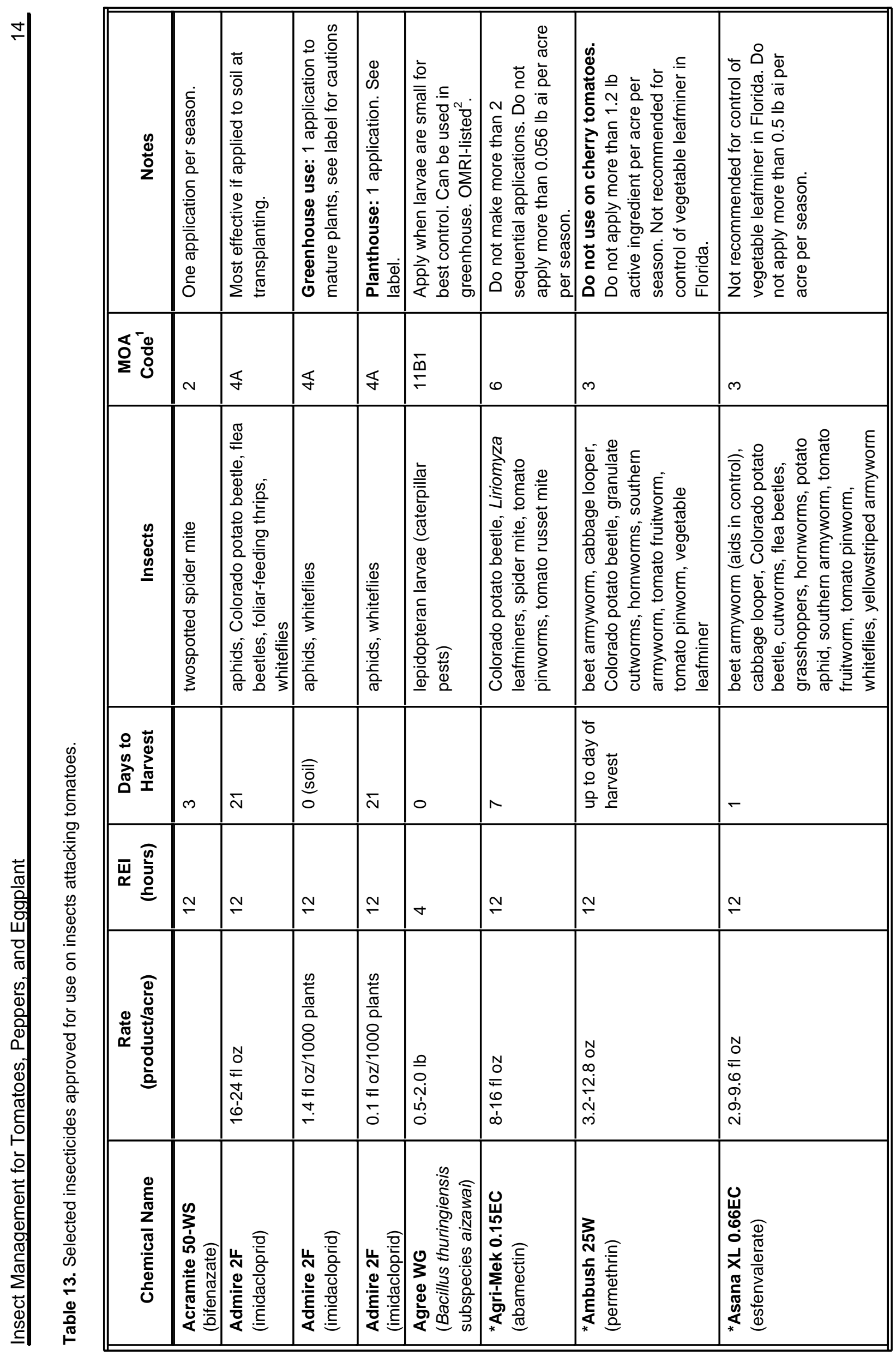




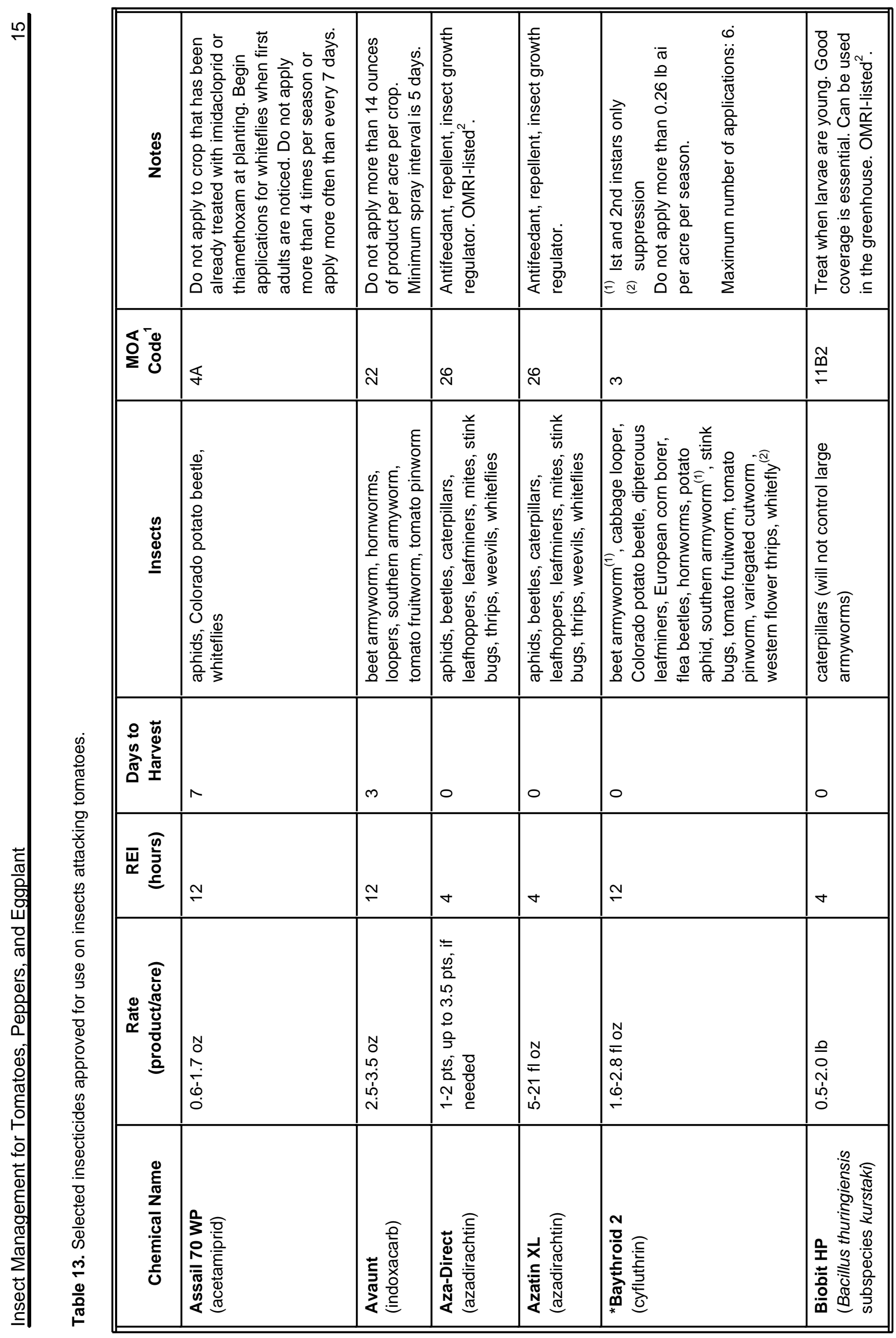




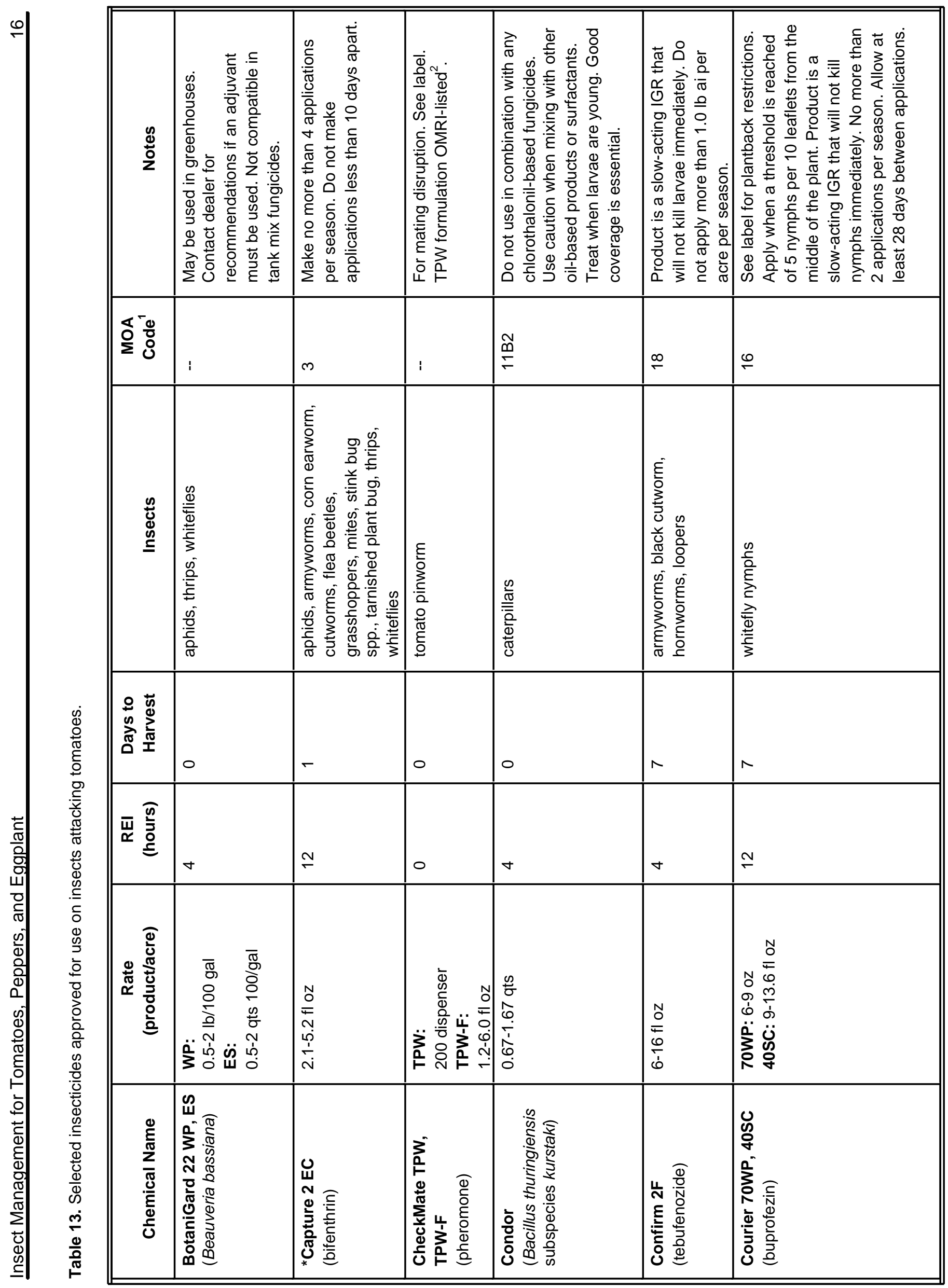




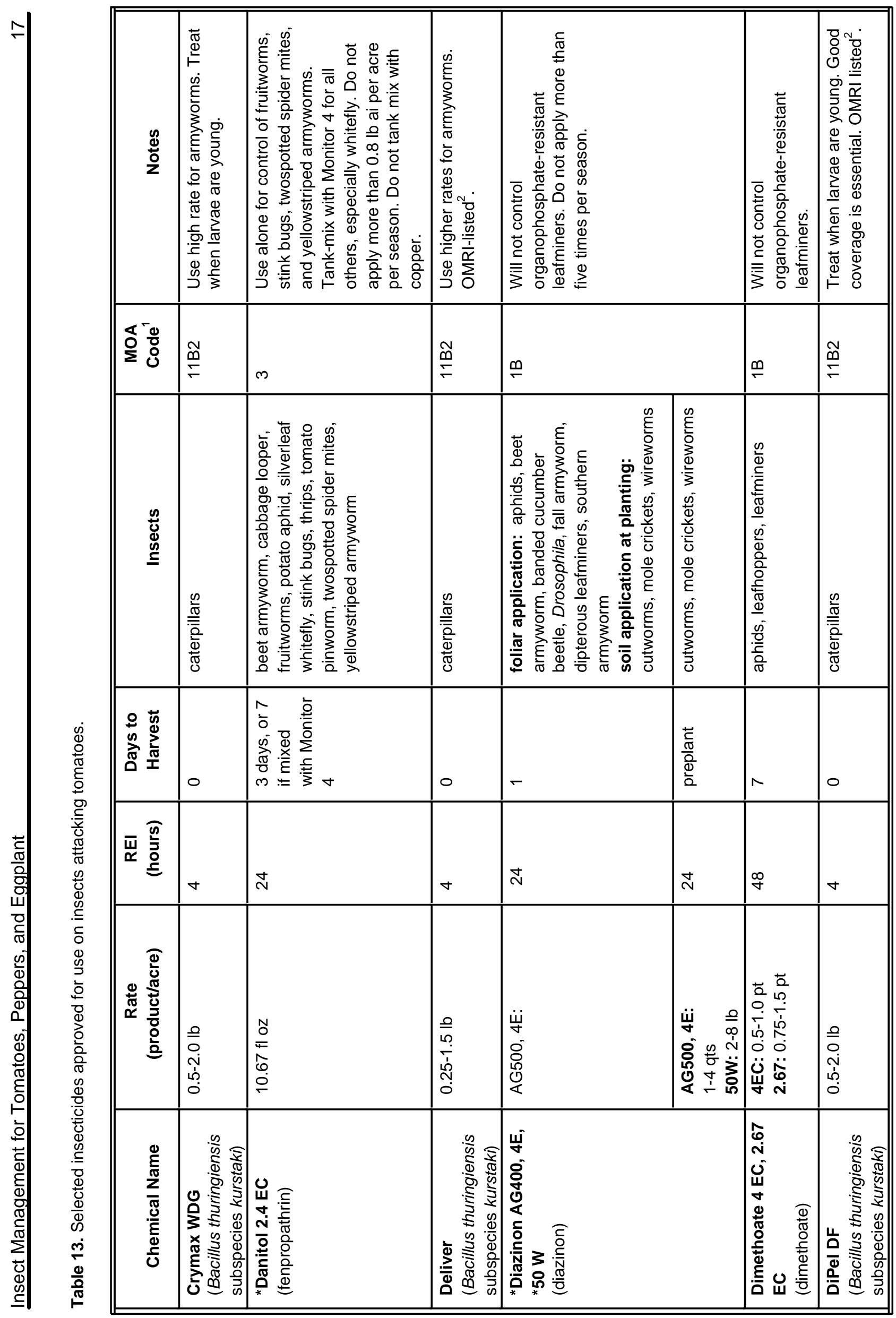




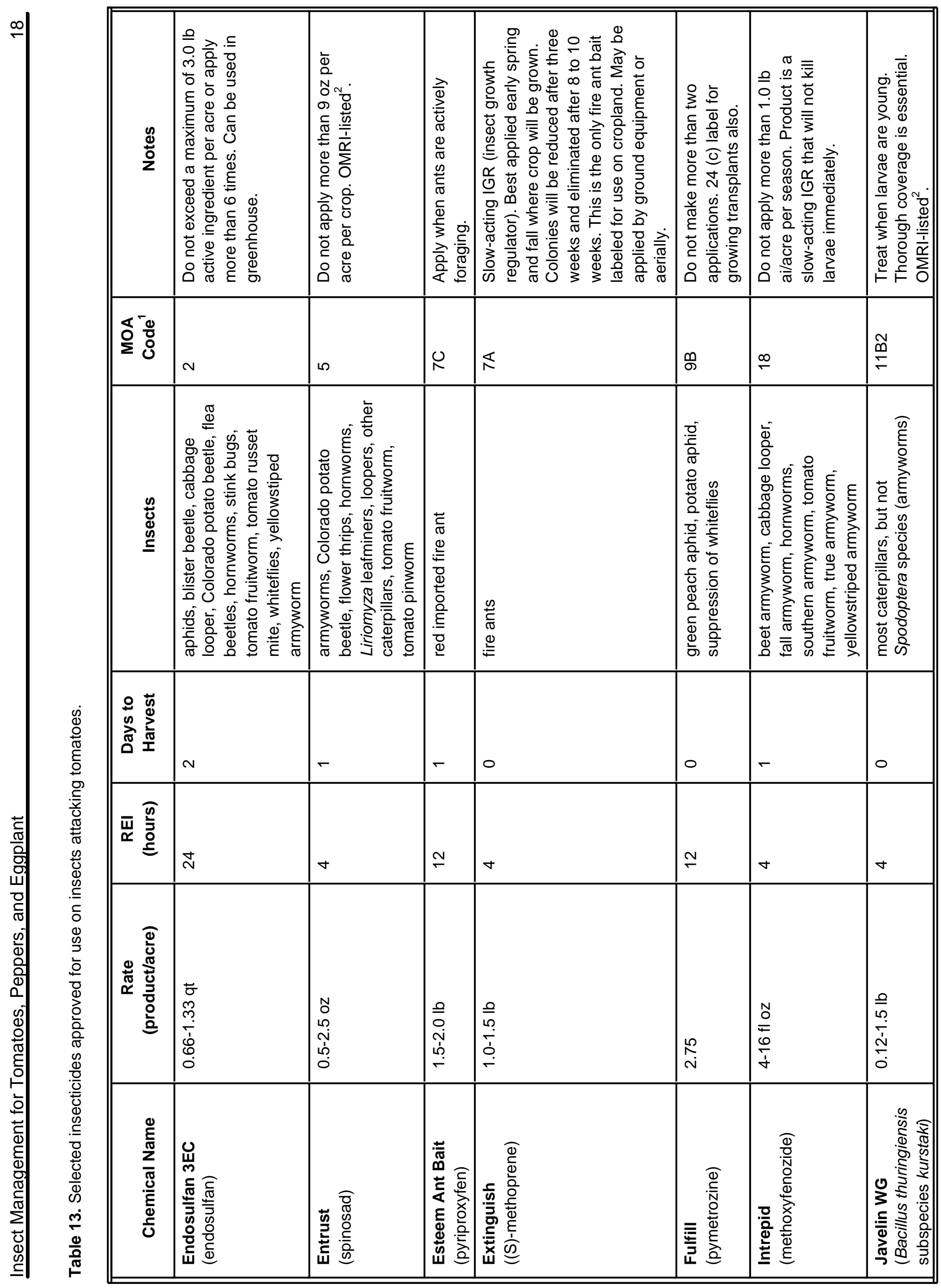




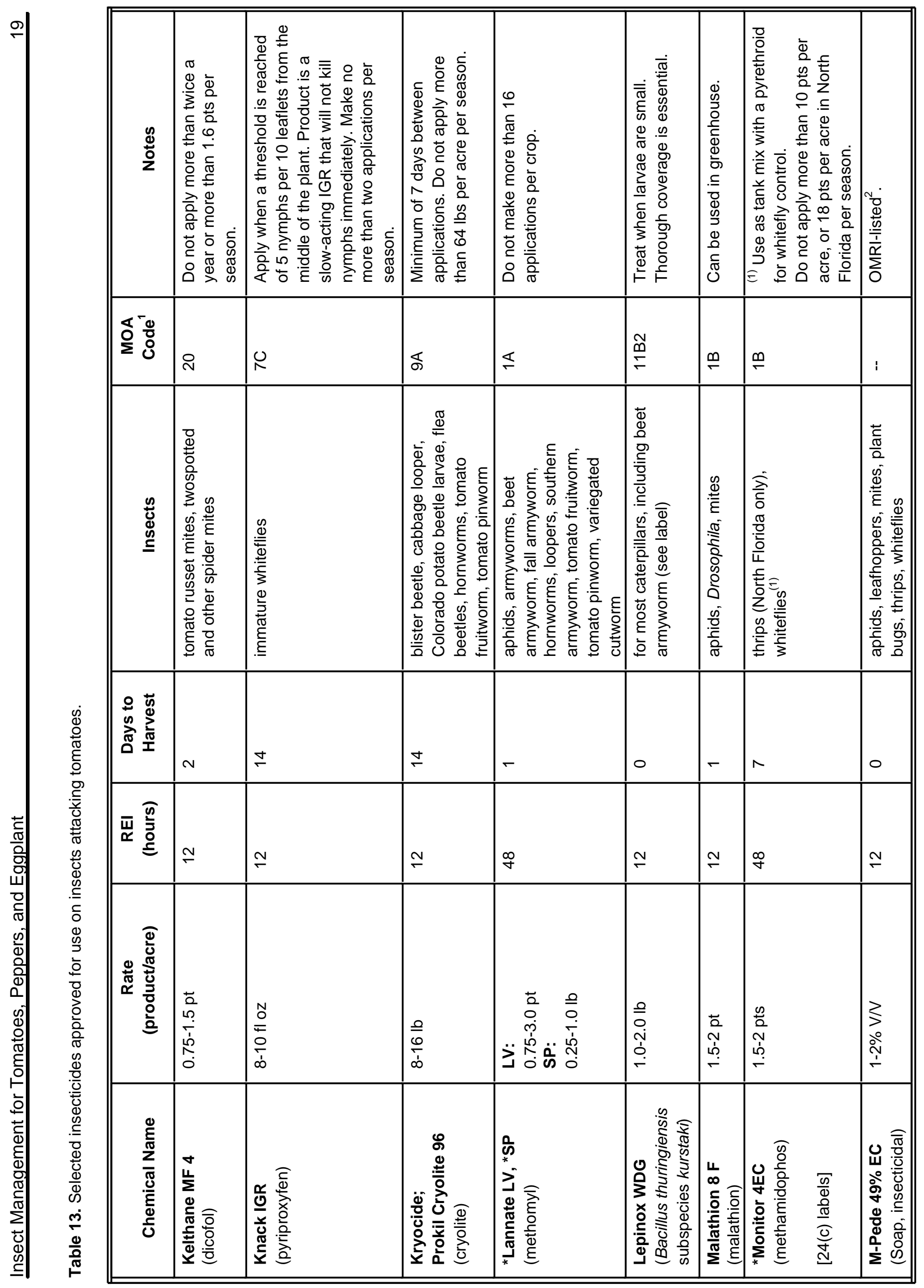




\begin{tabular}{|c|c|c|c|c|c|c|}
\hline 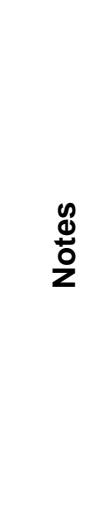 & 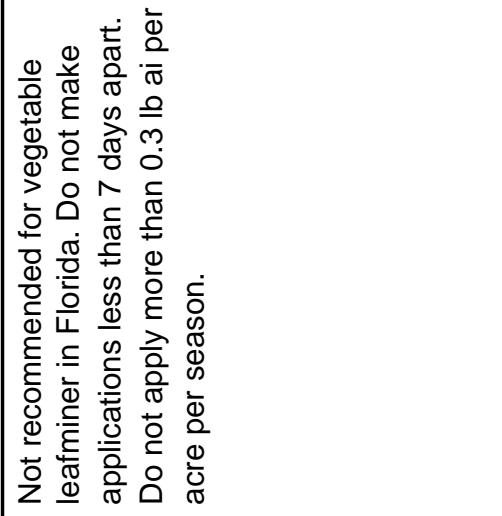 & 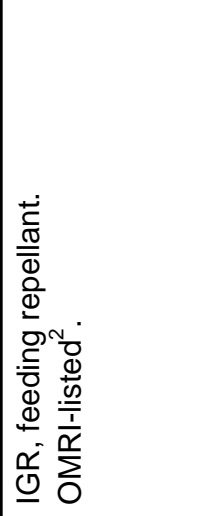 & 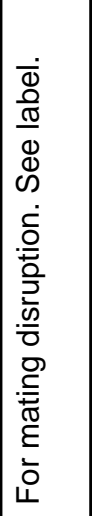 & 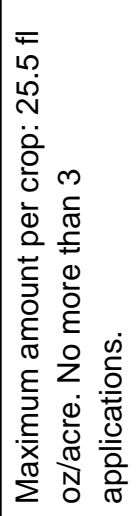 & 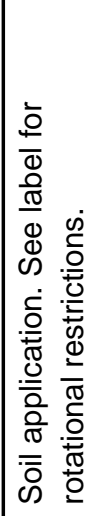 & 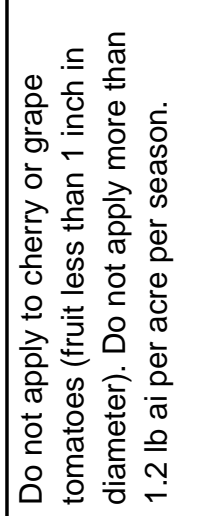 \\
\hline ¿̊ & m & 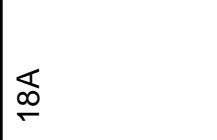 & 1 & $\mathbb{N}$ & $\varangle$ & m \\
\hline 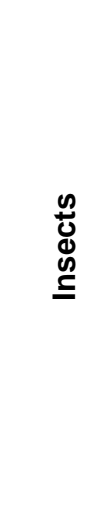 & 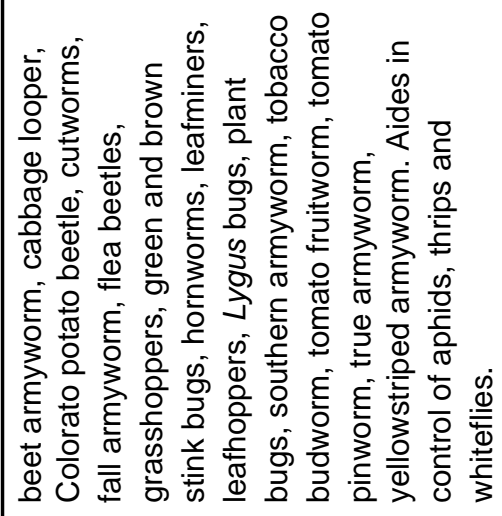 & 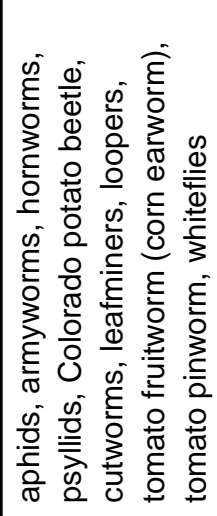 & 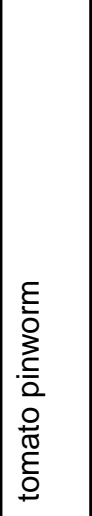 & 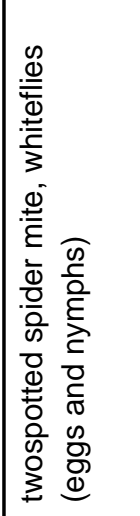 & 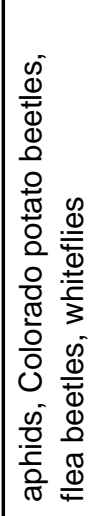 & 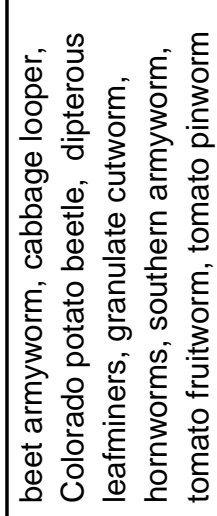 \\
\hline 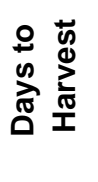 & - & 0 & 0 & $\wedge$ & পి & 0 \\
\hline 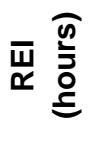 & $\cong$ & $\simeq$ & 0 & $\stackrel{\simeq}{\sim}$ & $\cong$ & $\cong$ \\
\hline 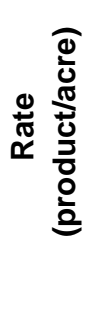 & 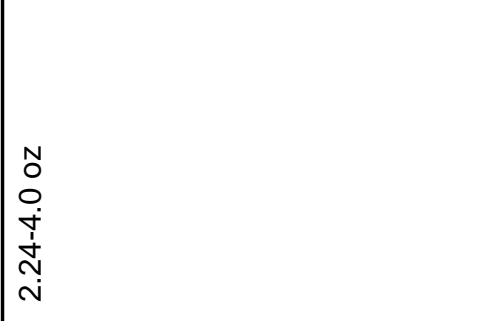 & 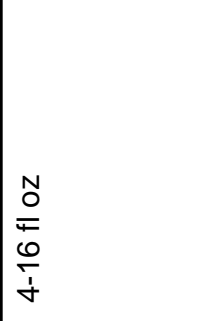 & & 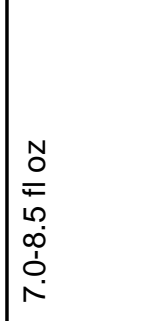 & 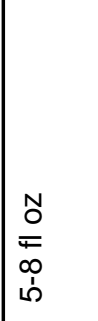 & $\begin{array}{l}N \\
O \\
\infty \\
⿱ \\
N \\
N\end{array}$ \\
\hline 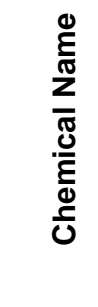 & 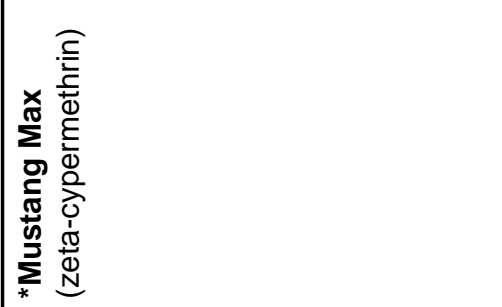 & 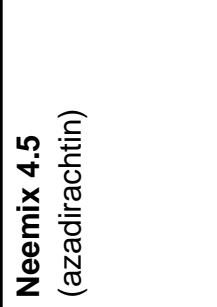 & 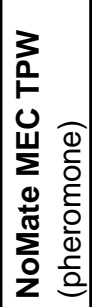 & 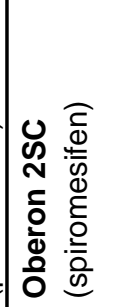 & 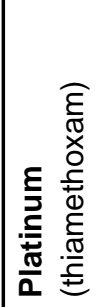 & 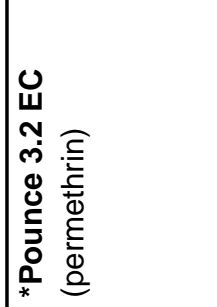 \\
\hline
\end{tabular}




\begin{tabular}{|c|c|c|c|c|c|}
\hline$\frac{\mathscr{g}}{\stackrel{0}{0}}$ & 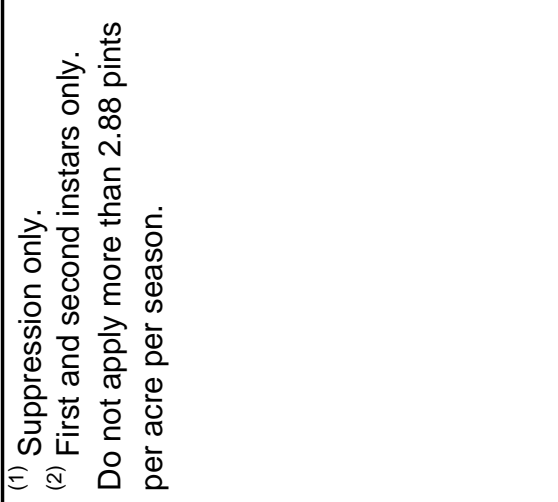 & 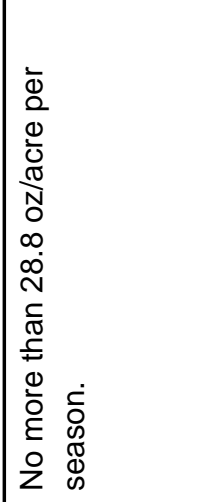 & 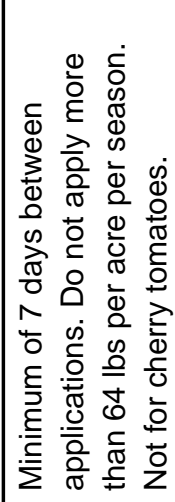 & 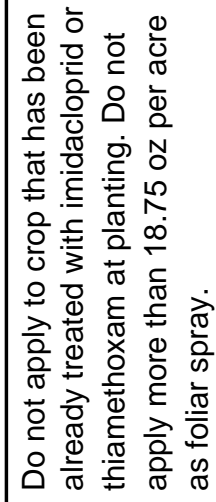 & \\
\hline ¿̊ & $m$ & 0 & চ & $\Varangle$ & $\begin{array}{l}\bar{N} \\
m^{-}\end{array}$ \\
\hline 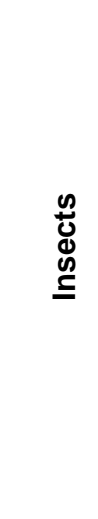 & 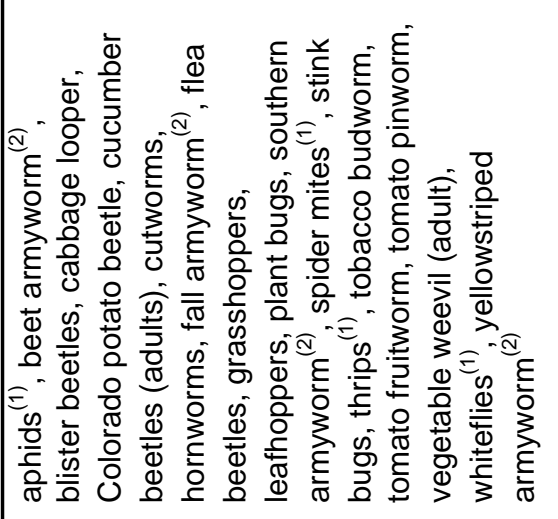 & 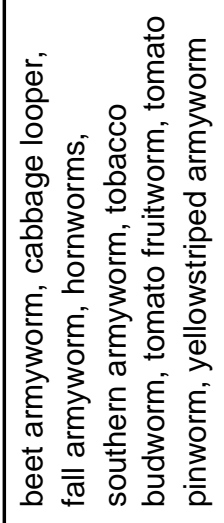 & 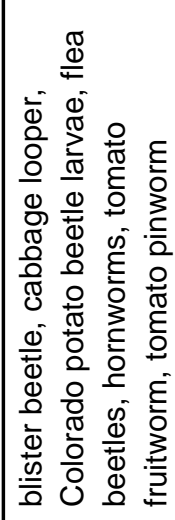 & 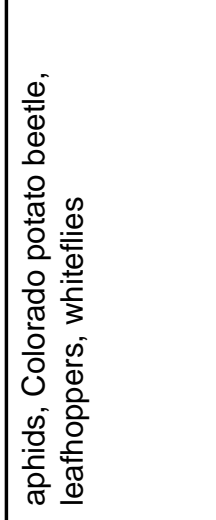 & 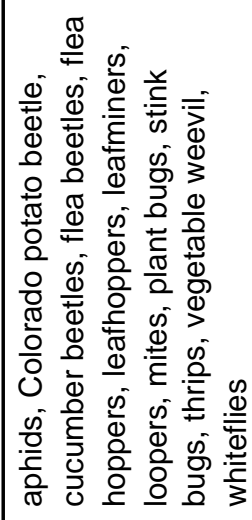 \\
\hline 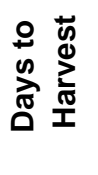 & ما & $\Lambda$ & $\stackrel{+}{\square}$ & $\begin{array}{l}\frac{\bar{\sigma}}{0} \\
\frac{-0}{0} \\
\vdots \\
0\end{array}$ & 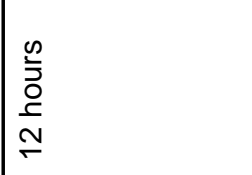 \\
\hline 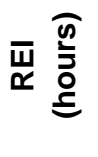 & $\stackrel{d}{N}$ & 过 & $\cong$ & $\cong$ & $\cong$ \\
\hline 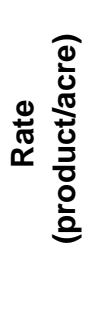 & 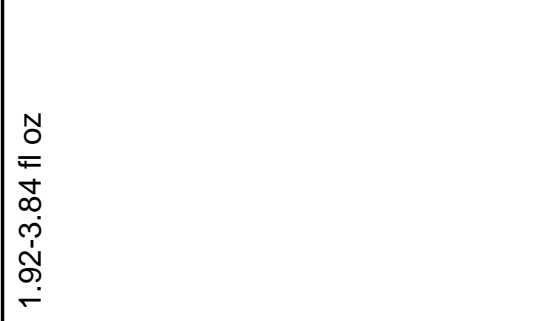 & $\begin{array}{l}N \\
O \\
\infty \\
\dot{J} \\
\dot{J} \\
\dot{d} \\
\end{array}$ & $\begin{array}{l}0 \\
0 \\
0 \\
0\end{array}$ & $\begin{array}{l}N \\
O \\
\infty \\
\\
\dot{m}\end{array}$ & $\begin{array}{l}\vec{\alpha} \\
\stackrel{N}{\sim} \\
\stackrel{\sim}{r}\end{array}$ \\
\hline 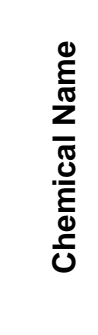 & 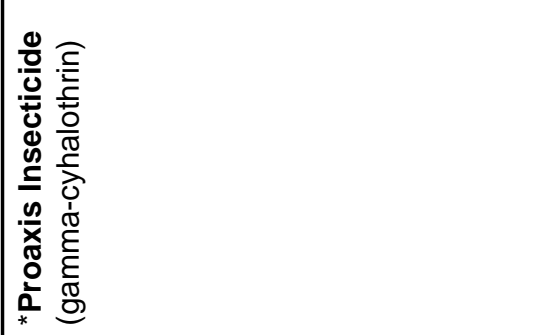 & 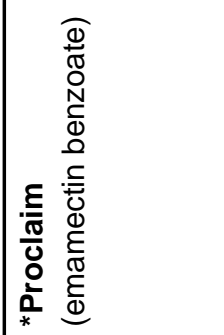 & 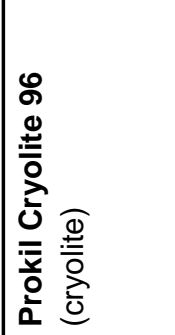 & 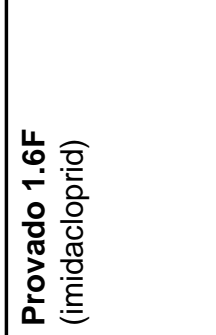 & 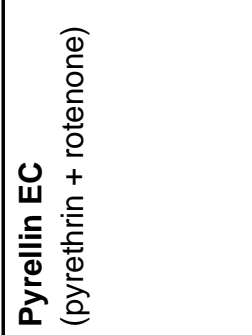 \\
\hline
\end{tabular}




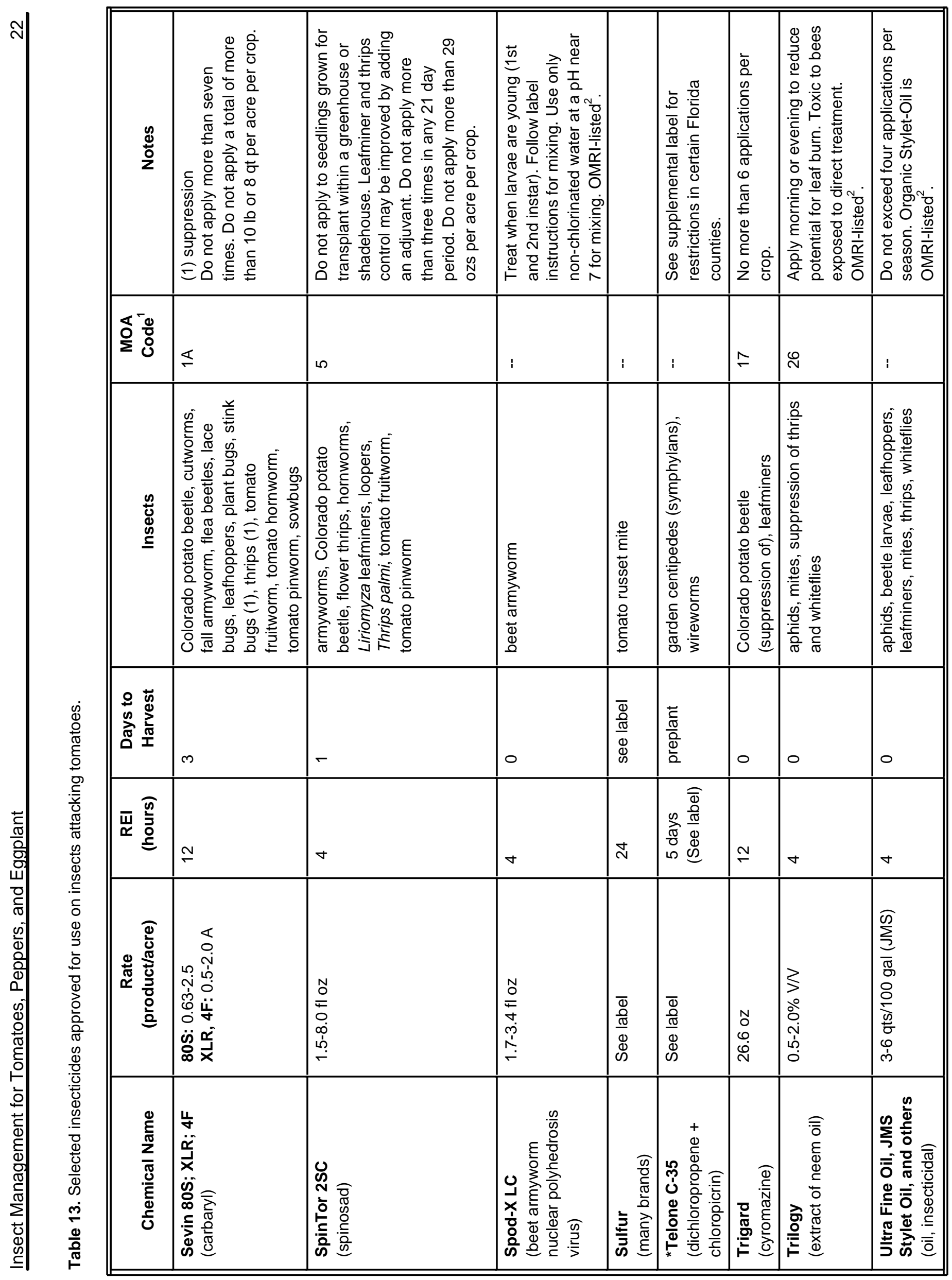




\begin{tabular}{|c|c|c|c|c|c|}
\hline $\begin{array}{l}\mathscr{\mathscr { y }} \\
\stackrel{0}{\mathbf{z}}\end{array}$ & 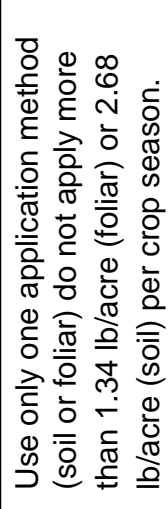 & 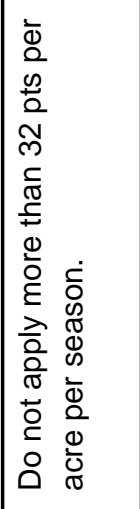 & 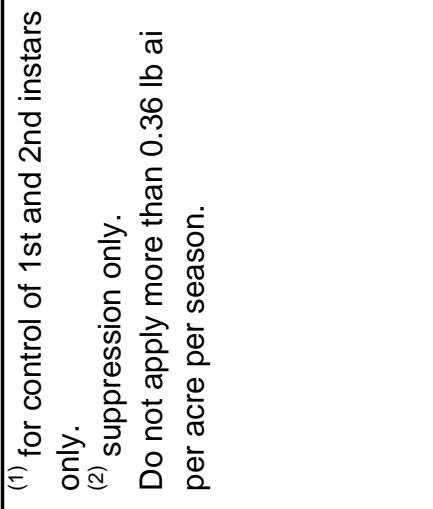 & 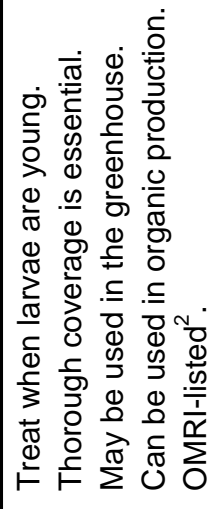 & 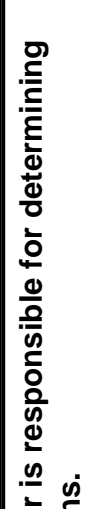 \\
\hline 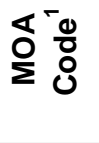 & $\underset{f}{\Varangle}$ & $\leqslant$ & $m$ & $\stackrel{\bar{m}}{\mp}$ & 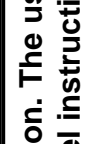 \\
\hline 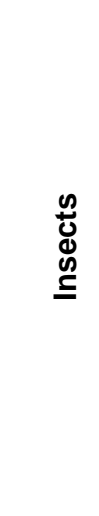 & 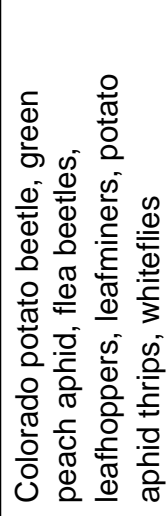 & 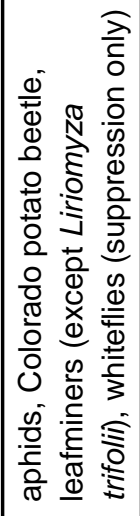 & 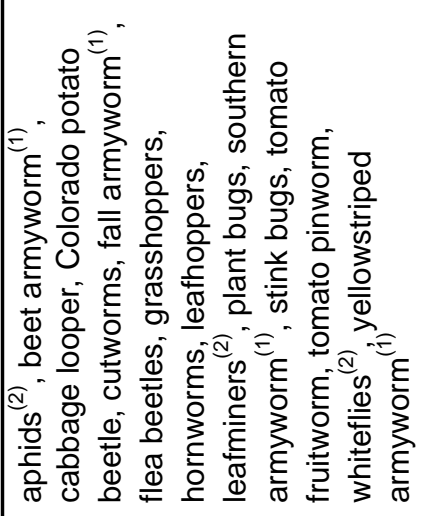 & 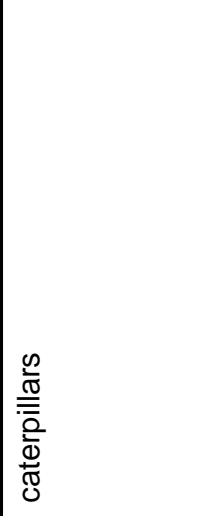 & 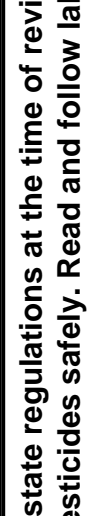 \\
\hline 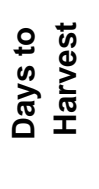 & 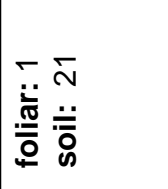 & $\infty$ & 10 & 0 & 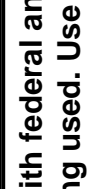 \\
\hline 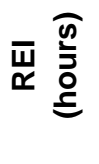 & $\stackrel{\sim}{\sim}$ & $\stackrel{\infty}{+}$ & $\stackrel{ম}{\sim}$ & $\forall$ & 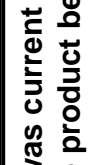 \\
\hline 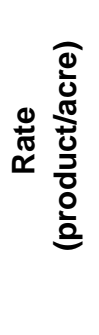 & 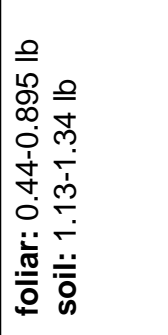 & 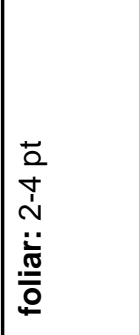 & 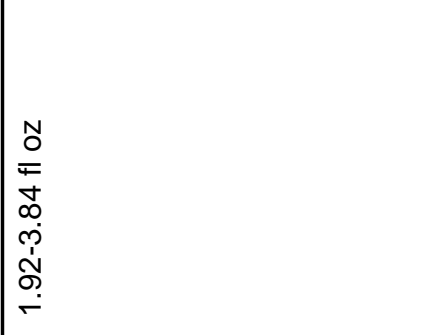 & 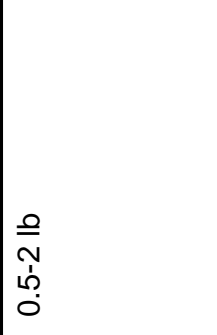 & 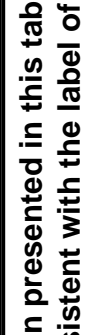 \\
\hline 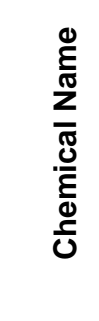 & 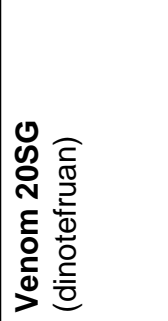 & 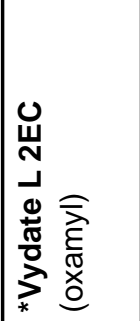 & 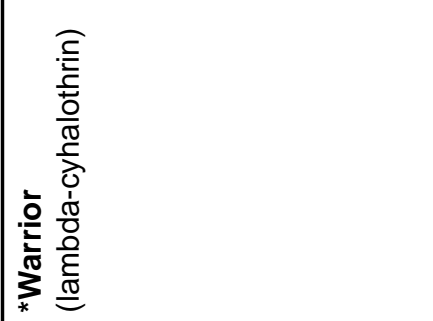 & 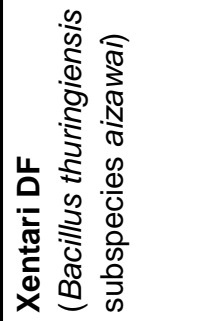 & 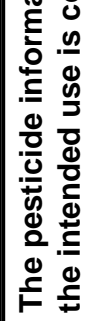 \\
\hline
\end{tabular}




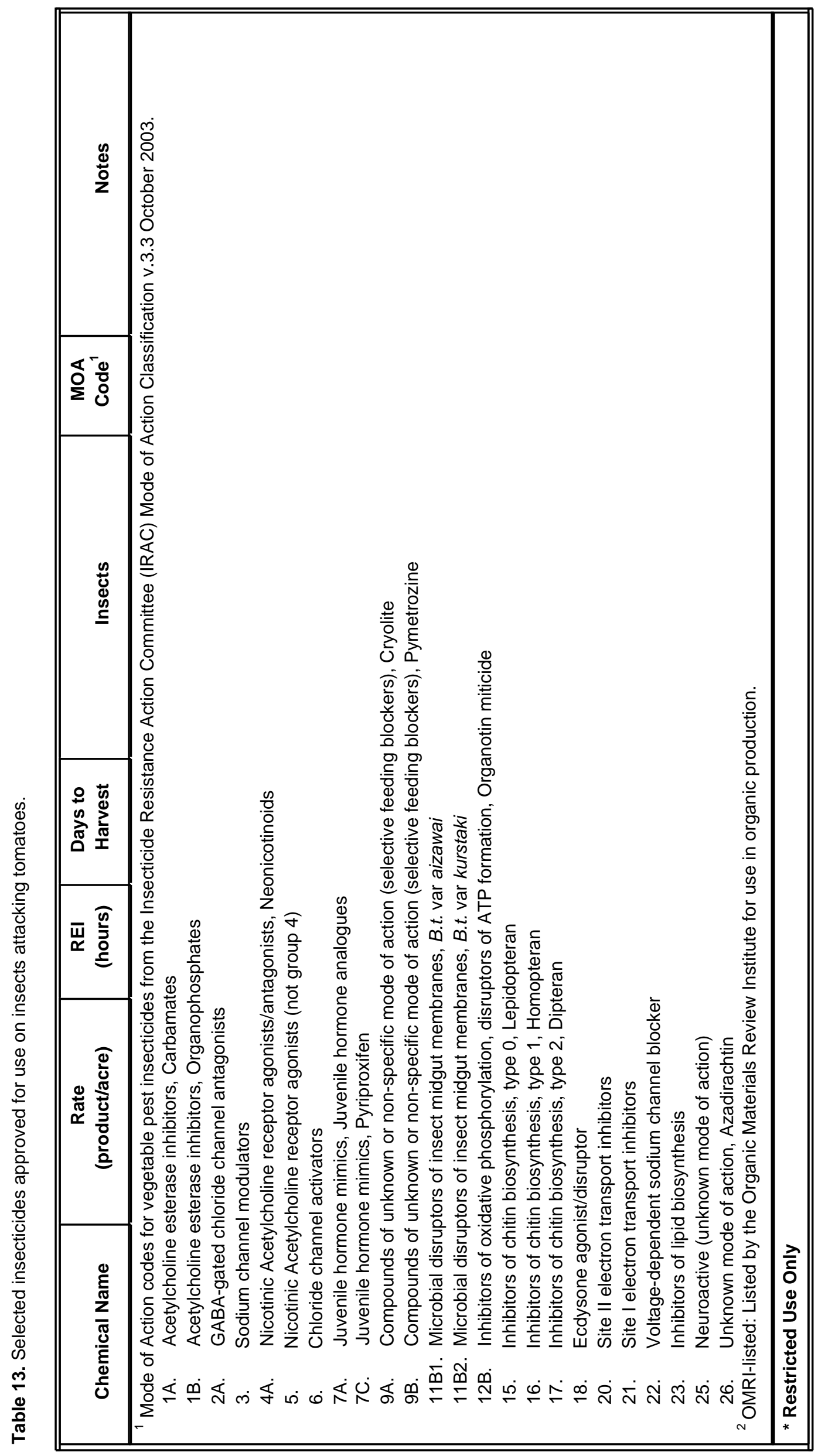




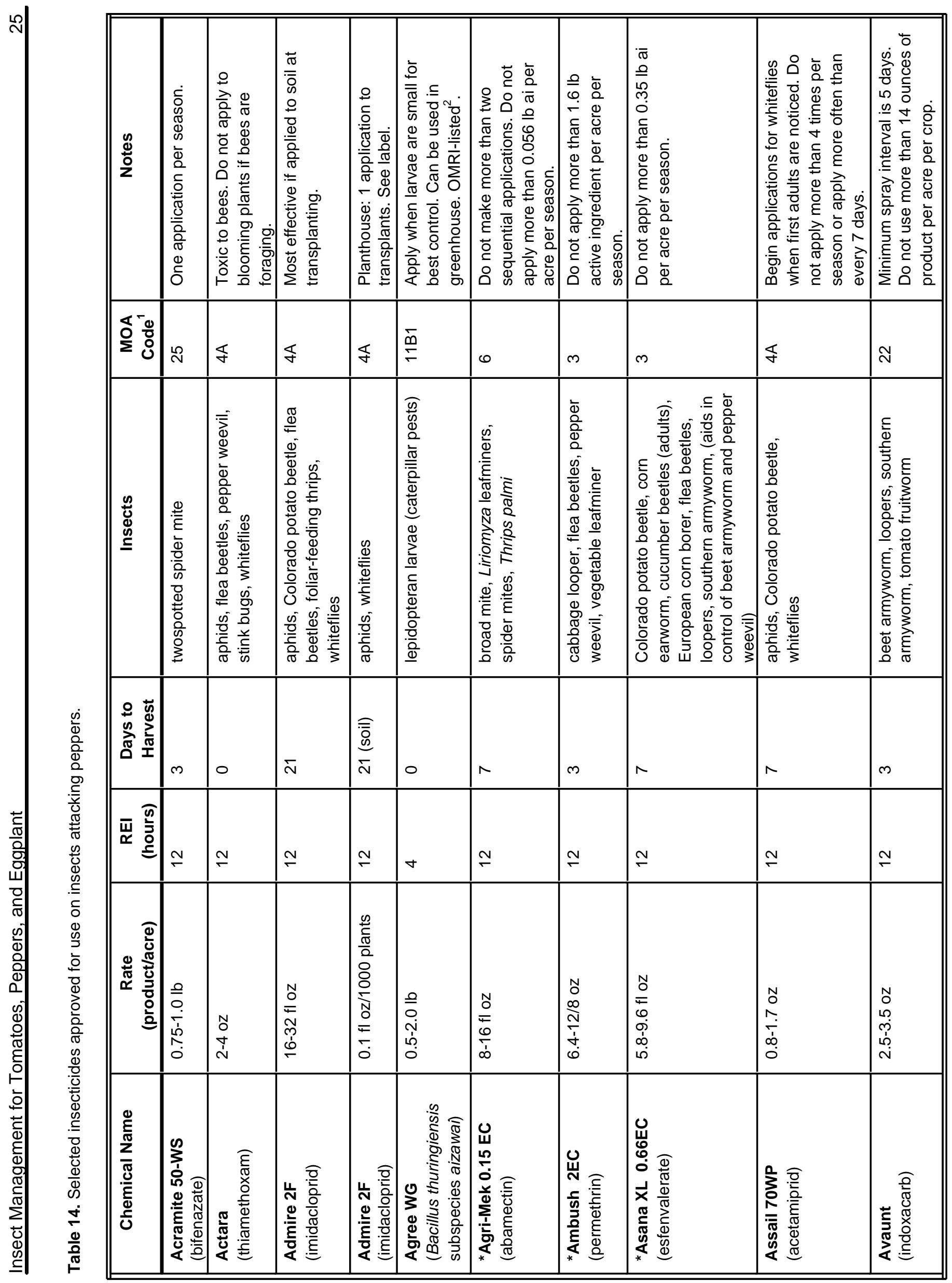




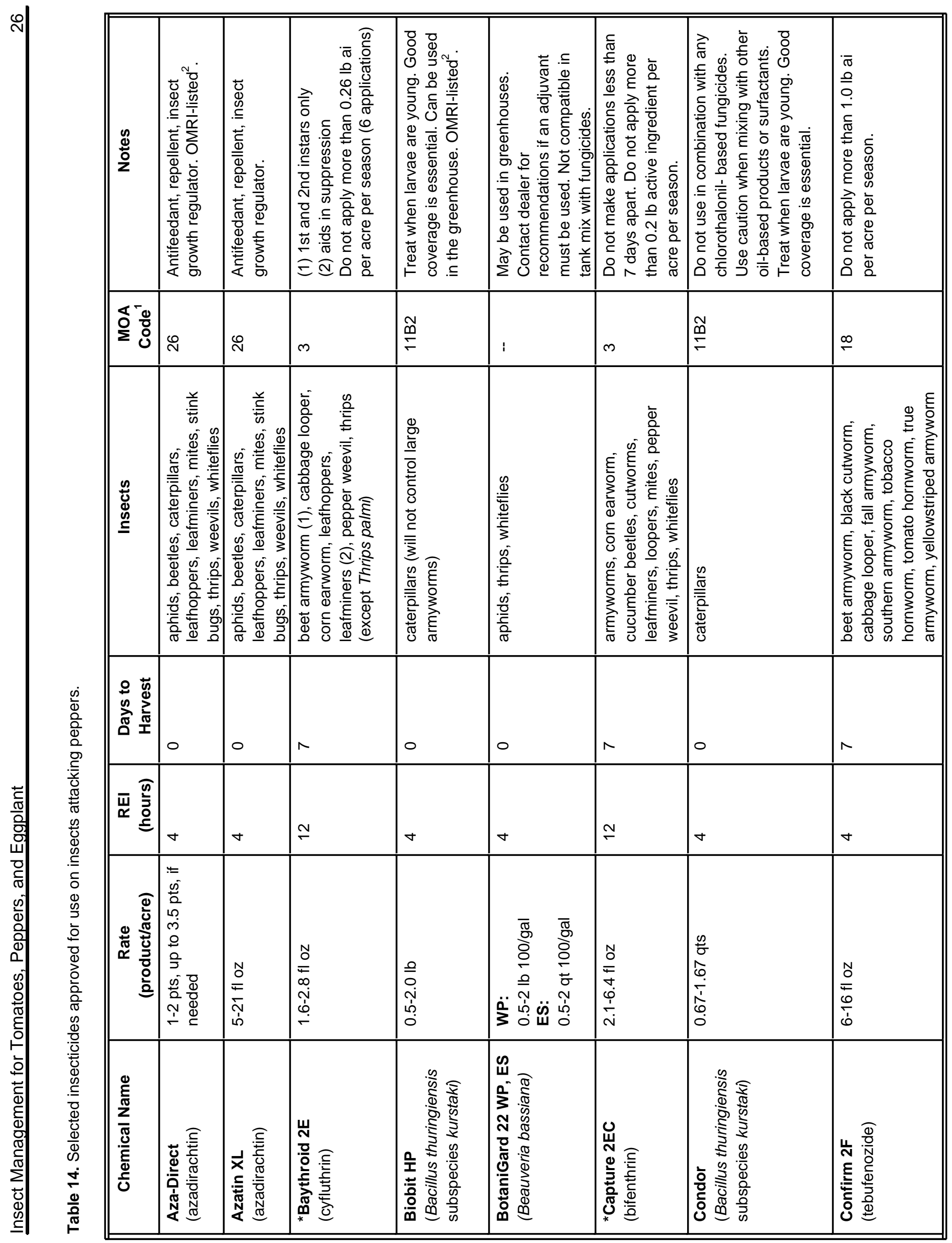




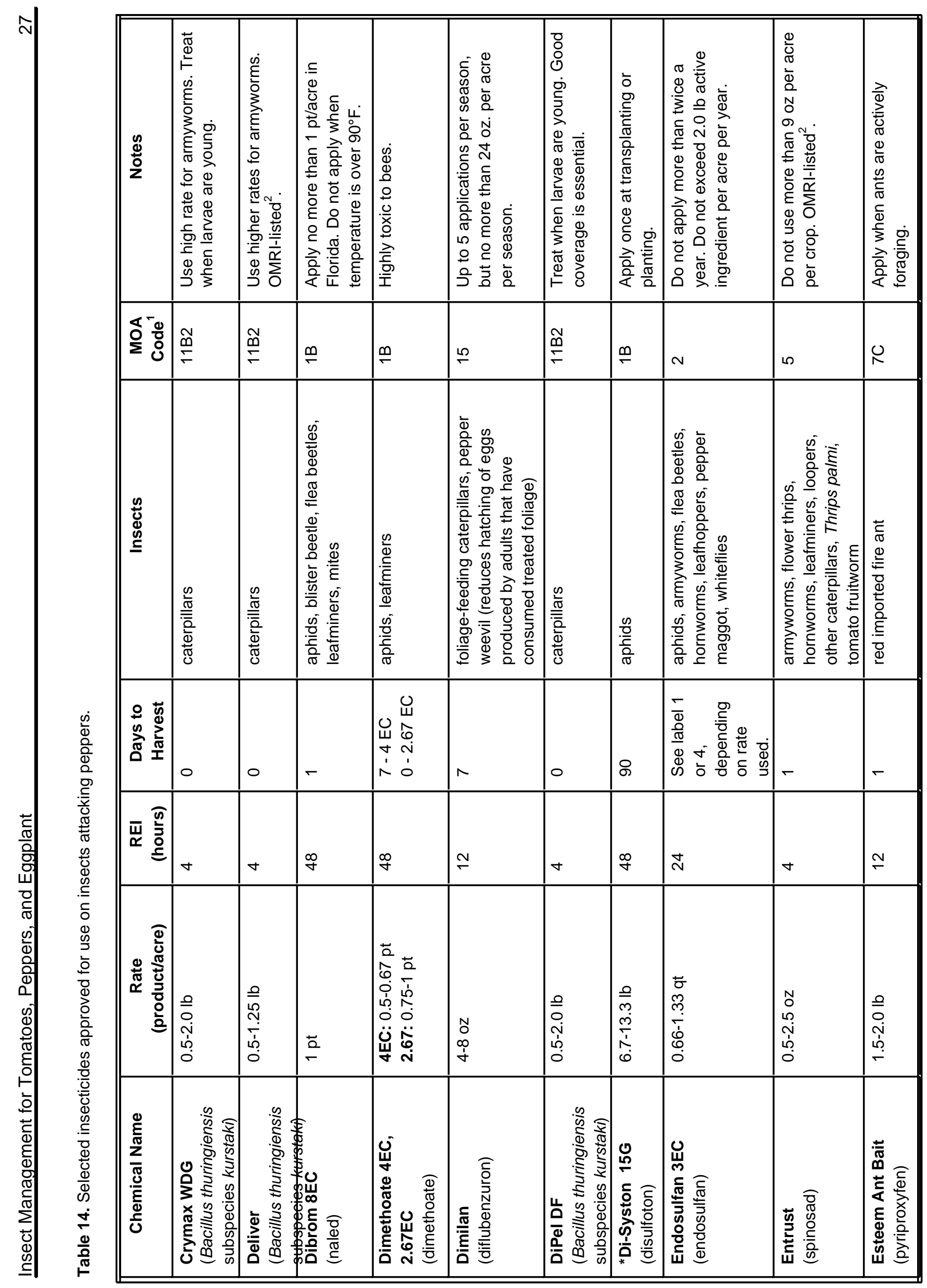




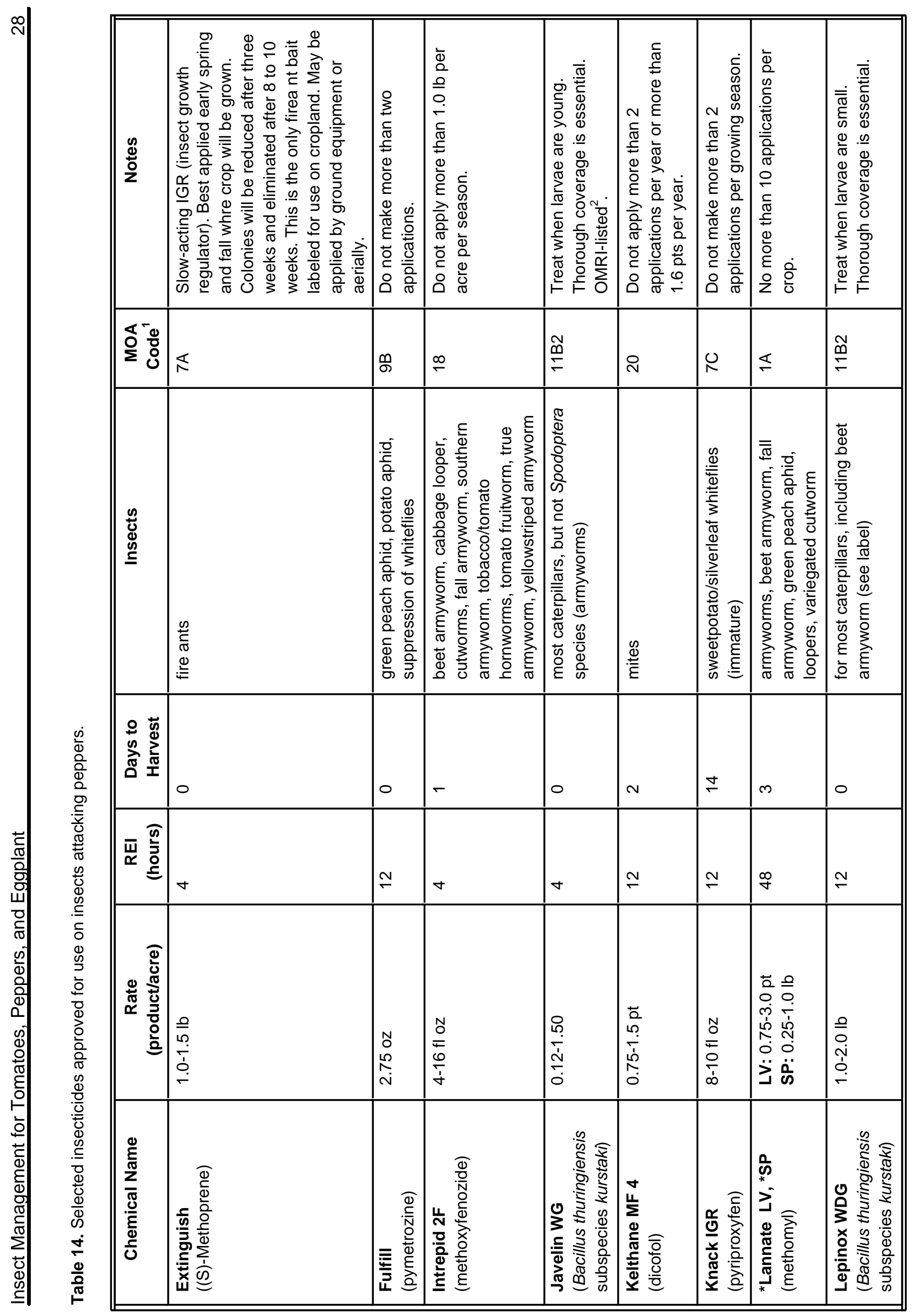




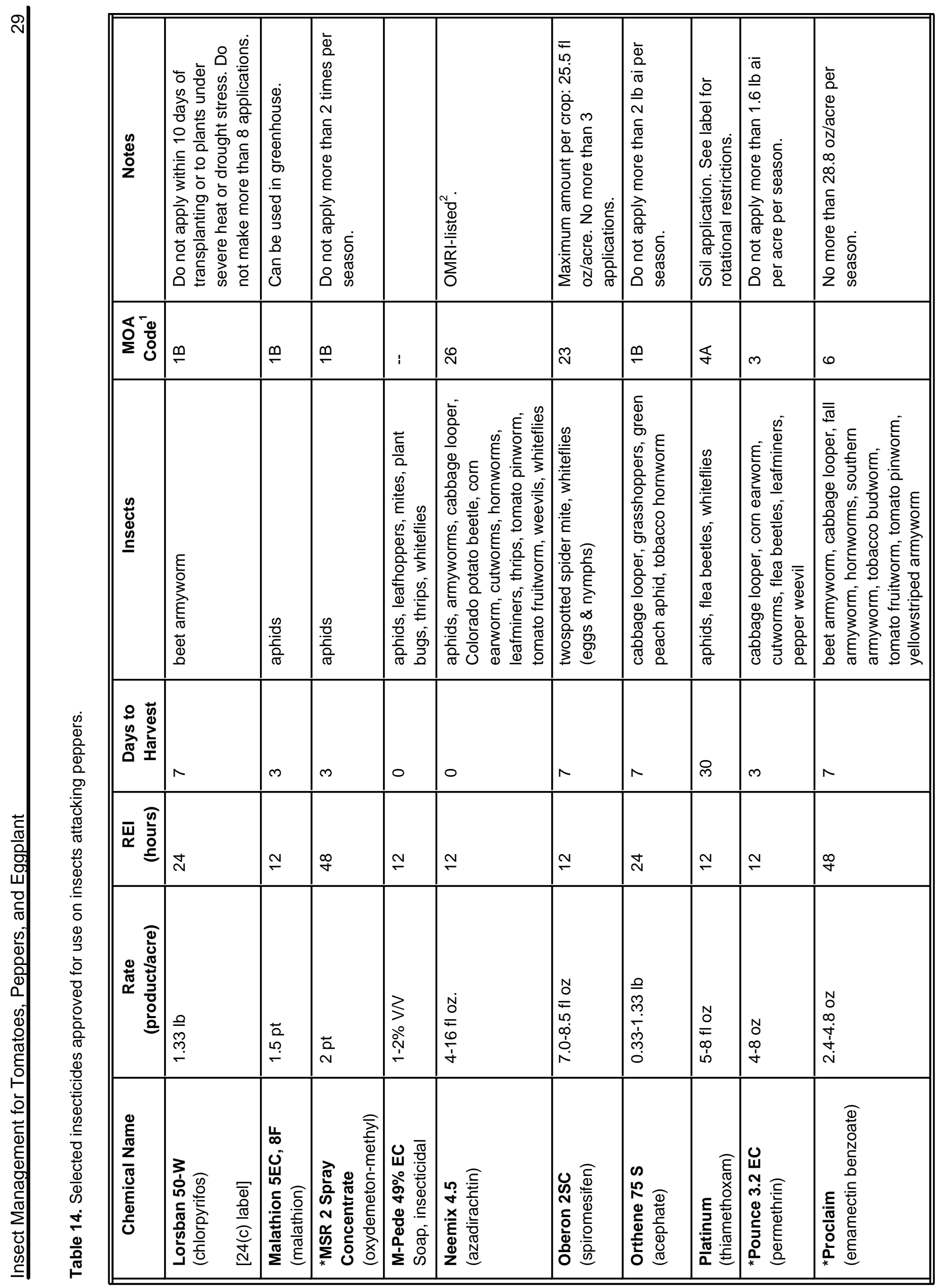




\begin{tabular}{|c|c|c|c|c|c|c|c|}
\hline $\mid$\begin{tabular}{|l}
$\mid \frac{y}{8}$ \\
$\frac{8}{2}$
\end{tabular} & 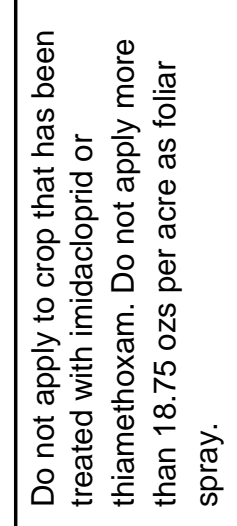 & & 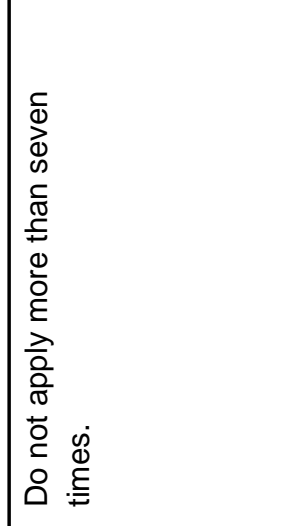 & 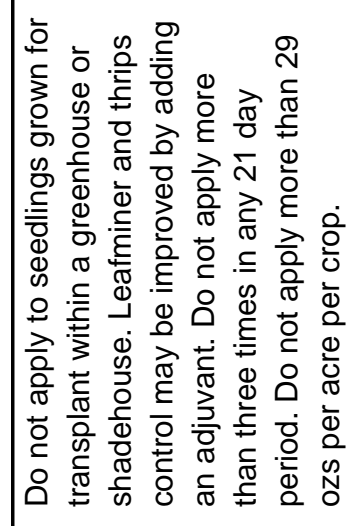 & 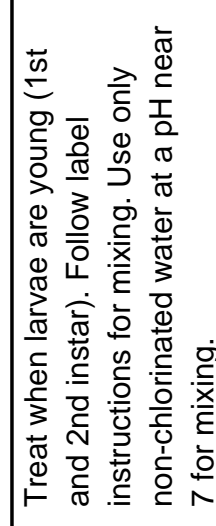 & 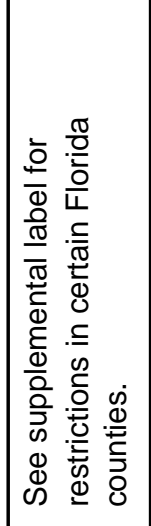 & 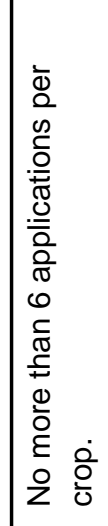 \\
\hline $\mid$ & 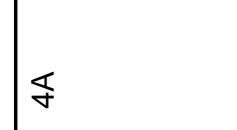 & $\mid \begin{array}{l}\bar{N} \\
\bar{c}\end{array}$ & 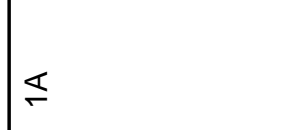 & ما & $:$ & : & $f$ \\
\hline 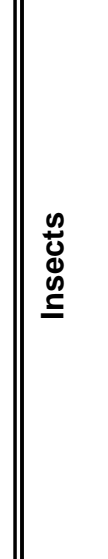 & 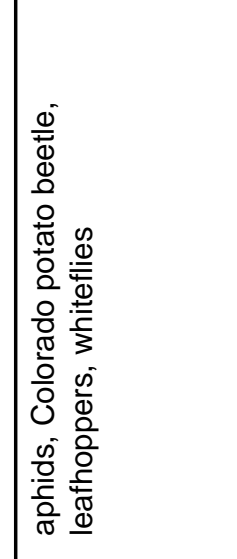 & 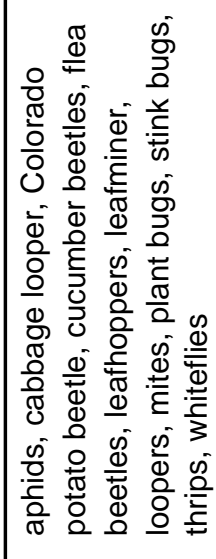 & 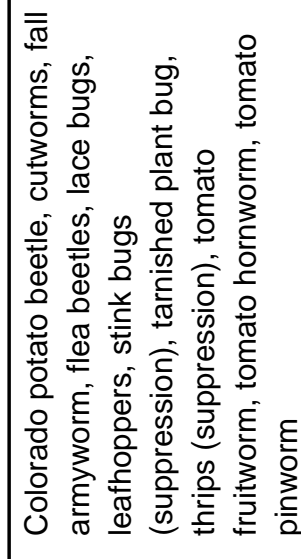 & 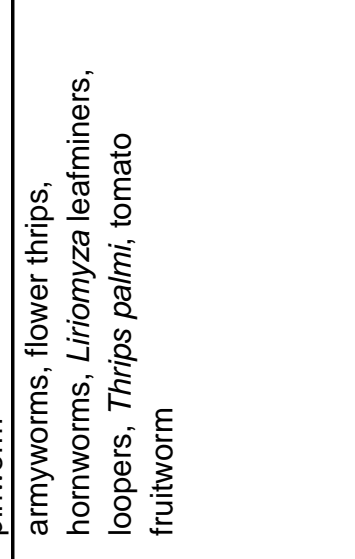 & 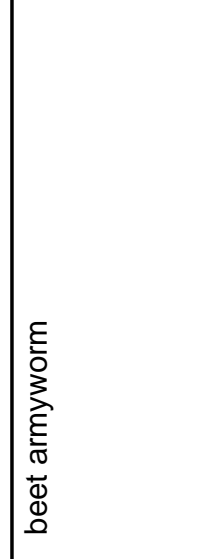 & 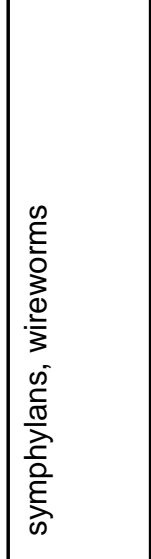 & 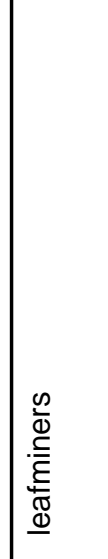 \\
\hline 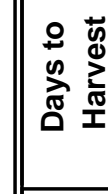 & 逞 & 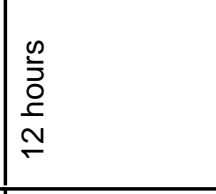 & m & I- & 10 & 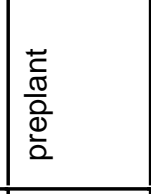 & 10 \\
\hline 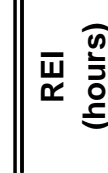 & $\cong$ & $\cong$ & $\simeq$ & | & | & 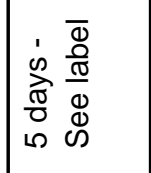 & $\simeq$ \\
\hline 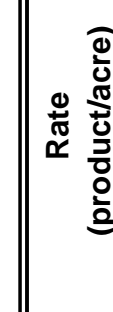 & 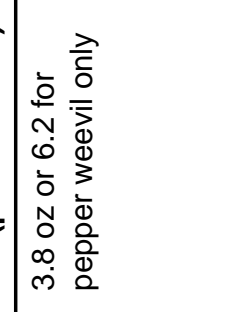 & 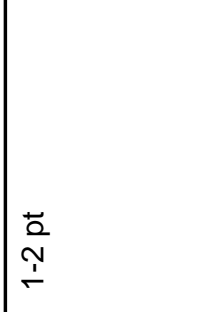 & 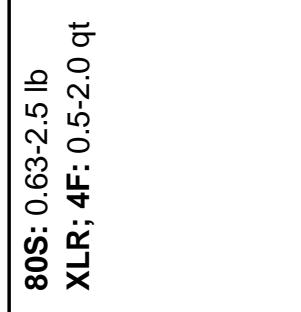 & 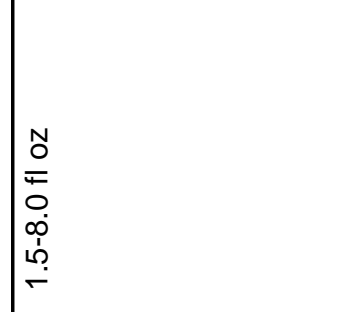 & 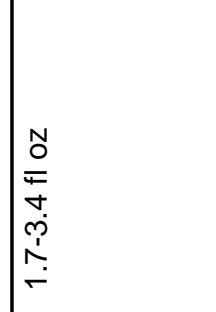 & 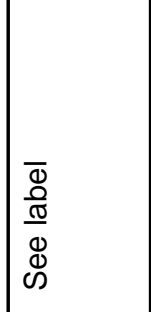 & 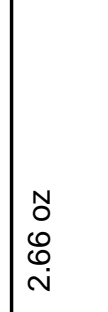 \\
\hline 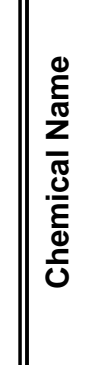 & 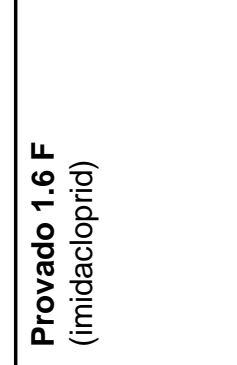 & 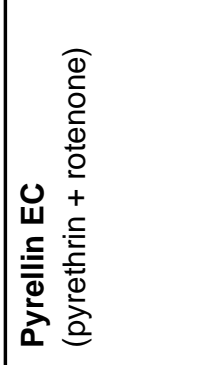 & 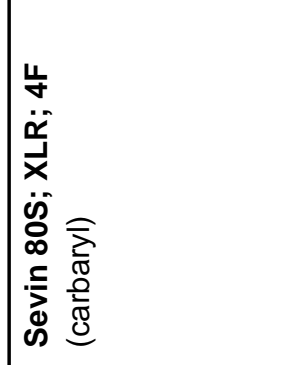 & 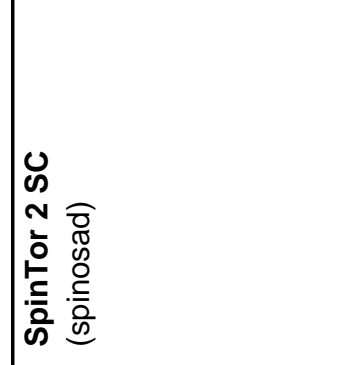 & 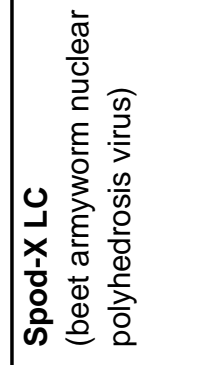 & 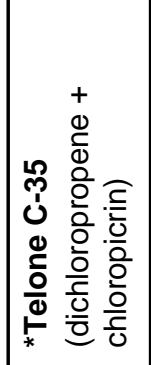 & 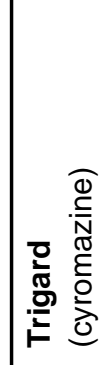 \\
\hline
\end{tabular}




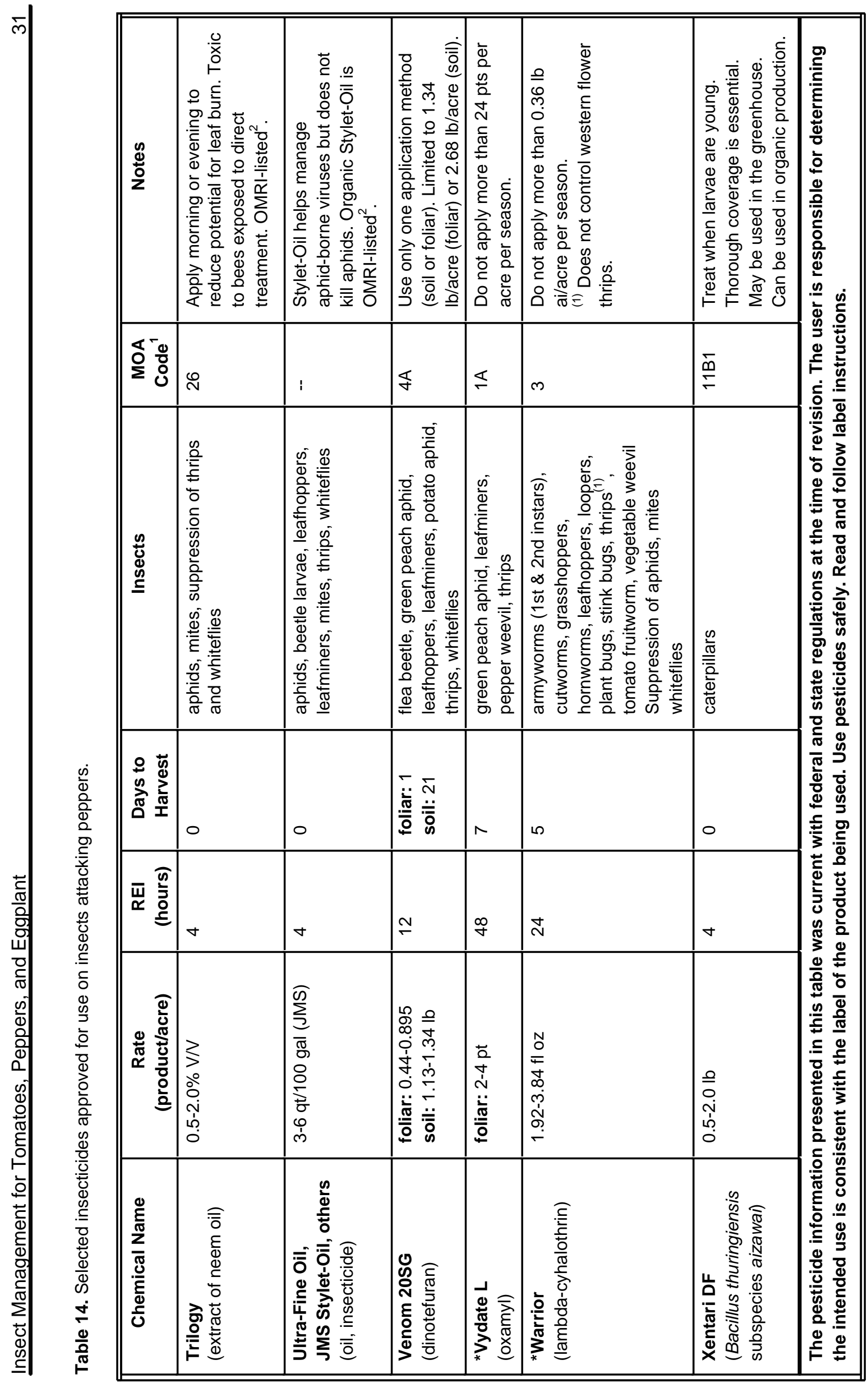




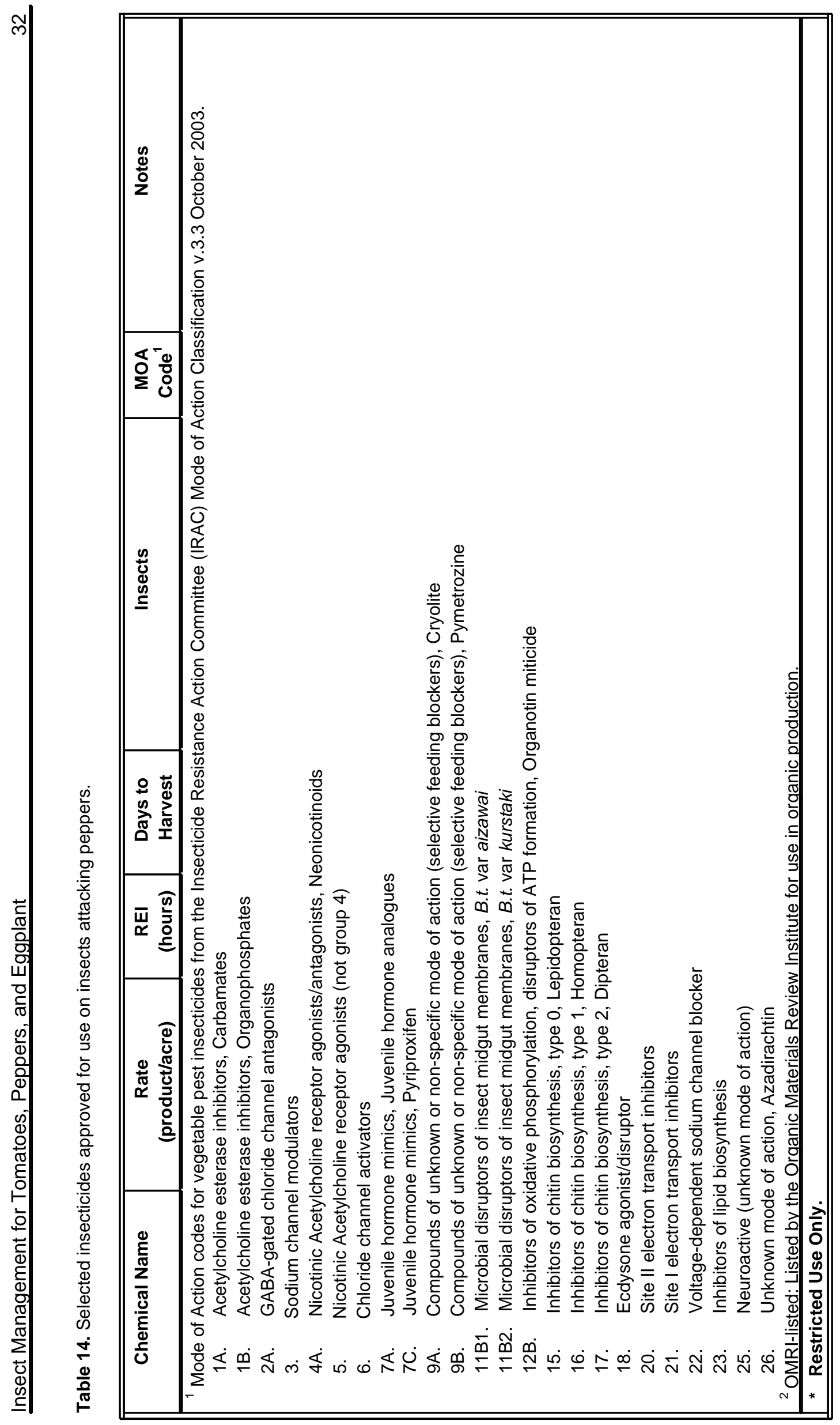




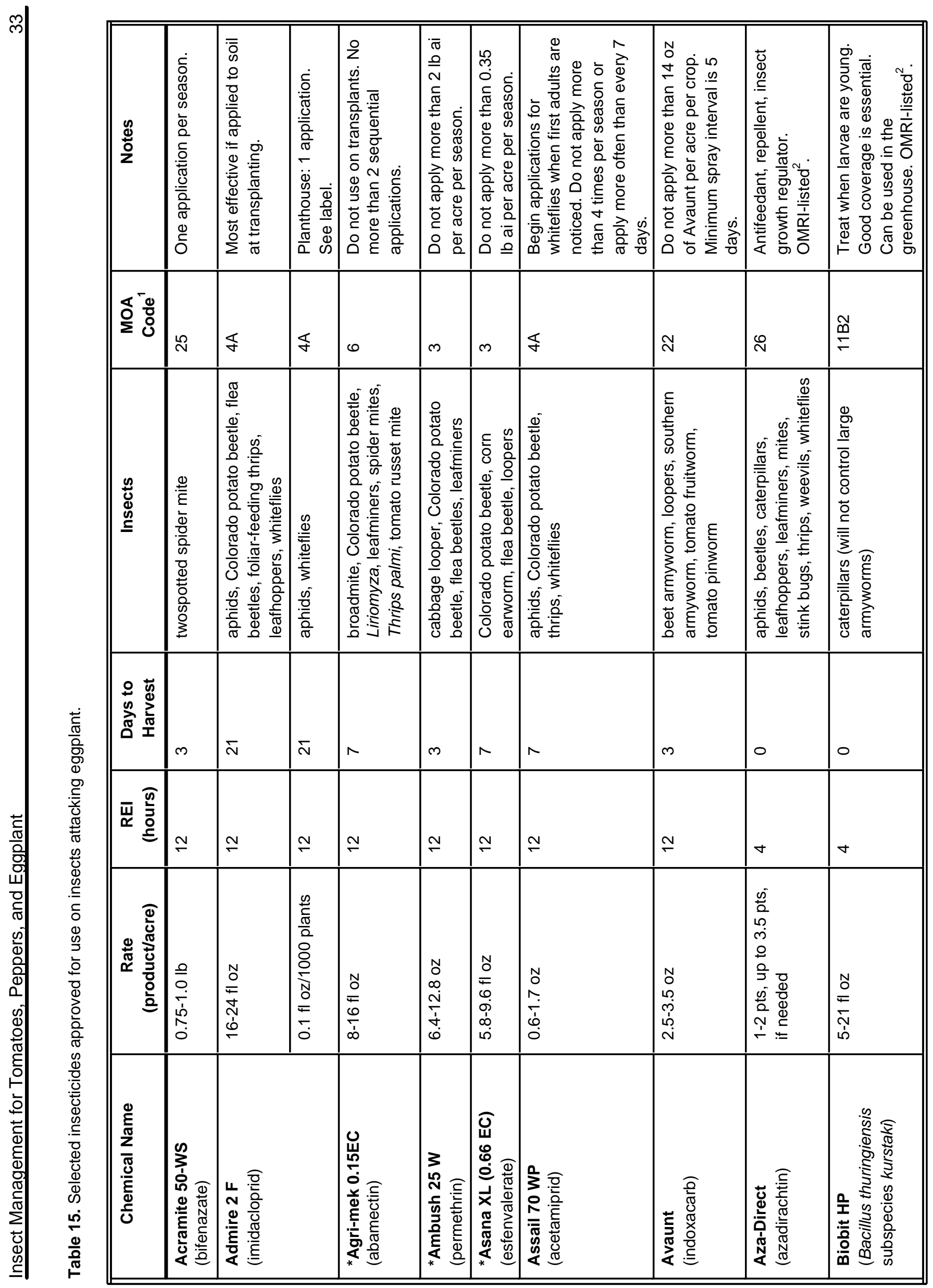




\begin{tabular}{|c|c|c|c|c|c|c|c|}
\hline 总 & 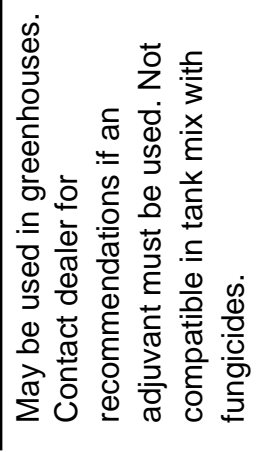 & 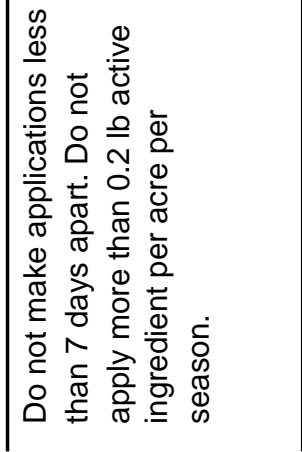 & 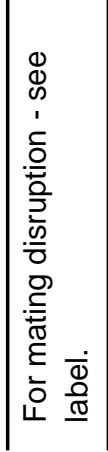 & 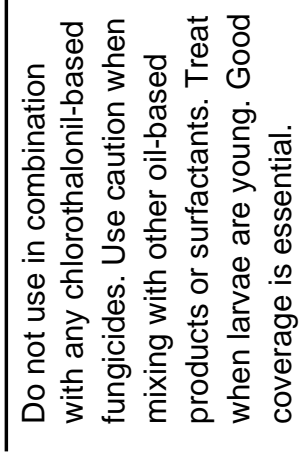 & 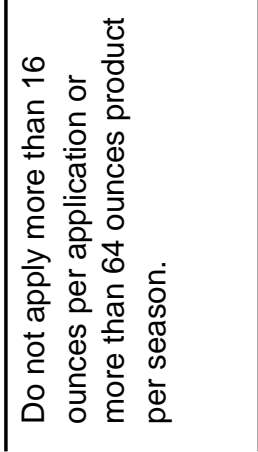 & 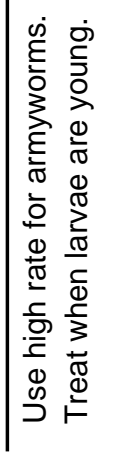 & 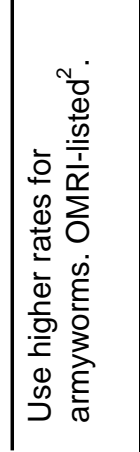 \\
\hline 造 & & m & : & 昰 & $\stackrel{\infty}{\longrightarrow}$ & 兽 & 兽 \\
\hline 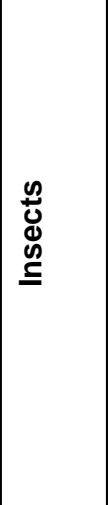 & 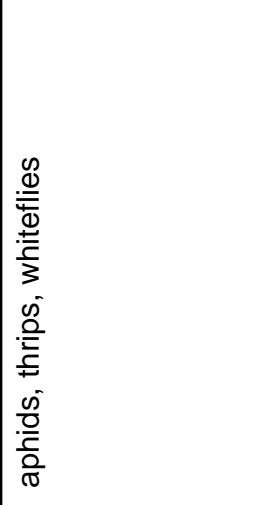 & 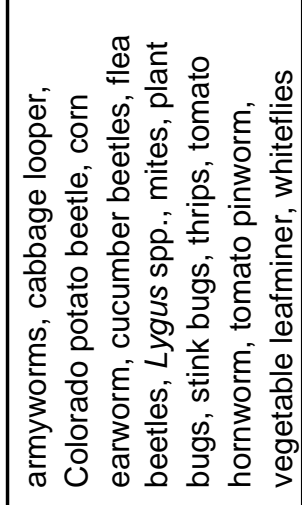 & 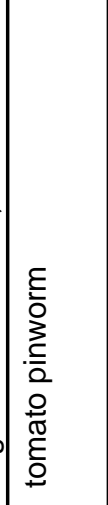 & 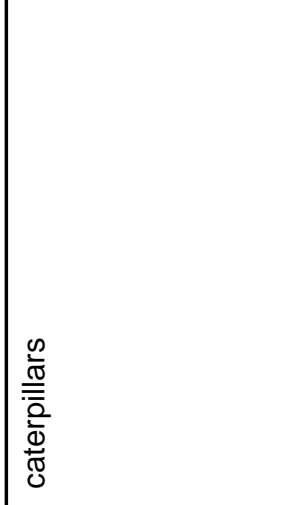 & 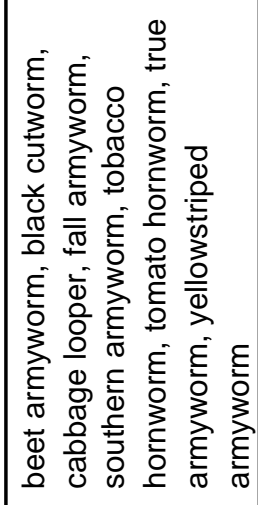 & 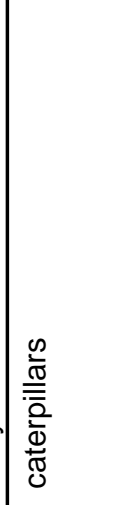 & 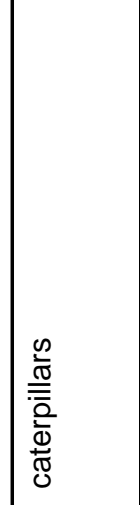 \\
\hline 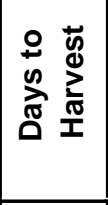 & 0 & Ir & 10 & 0 & $\wedge$ & 0 & 10 \\
\hline$\overline{\overline{\underline{x}}}$ & $\sigma$ & $\simeq$ & 0 & I & 1 & | & | \\
\hline 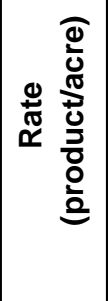 & 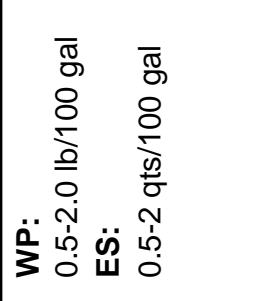 & 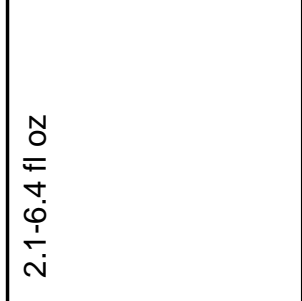 & 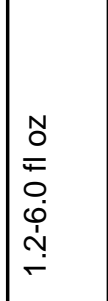 & 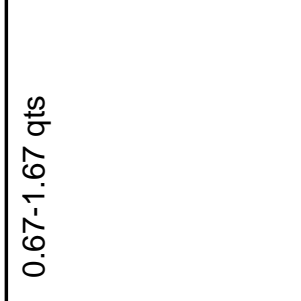 & \begin{tabular}{|l}
$\tilde{N}$ \\
$\stackrel{0}{0}$ \\
$\underline{0}$ \\
$\dot{0}$ \\
0
\end{tabular} & 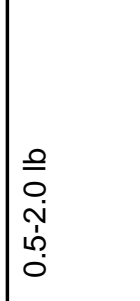 & 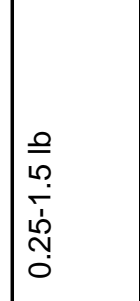 \\
\hline 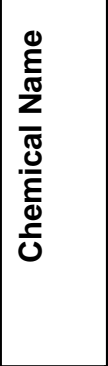 & 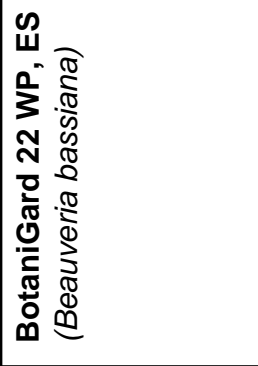 & 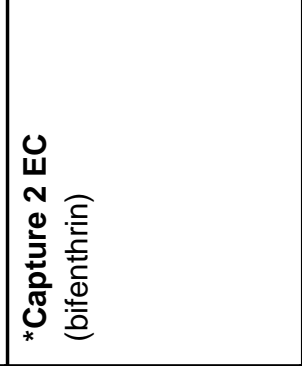 & 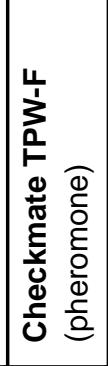 & 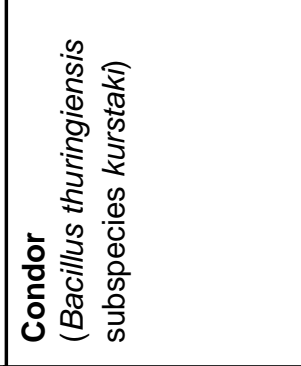 & 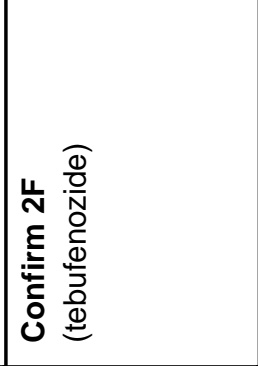 & 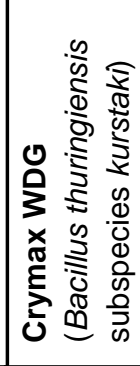 & 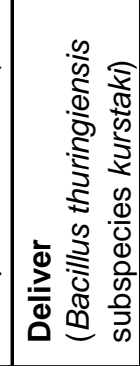 \\
\hline
\end{tabular}




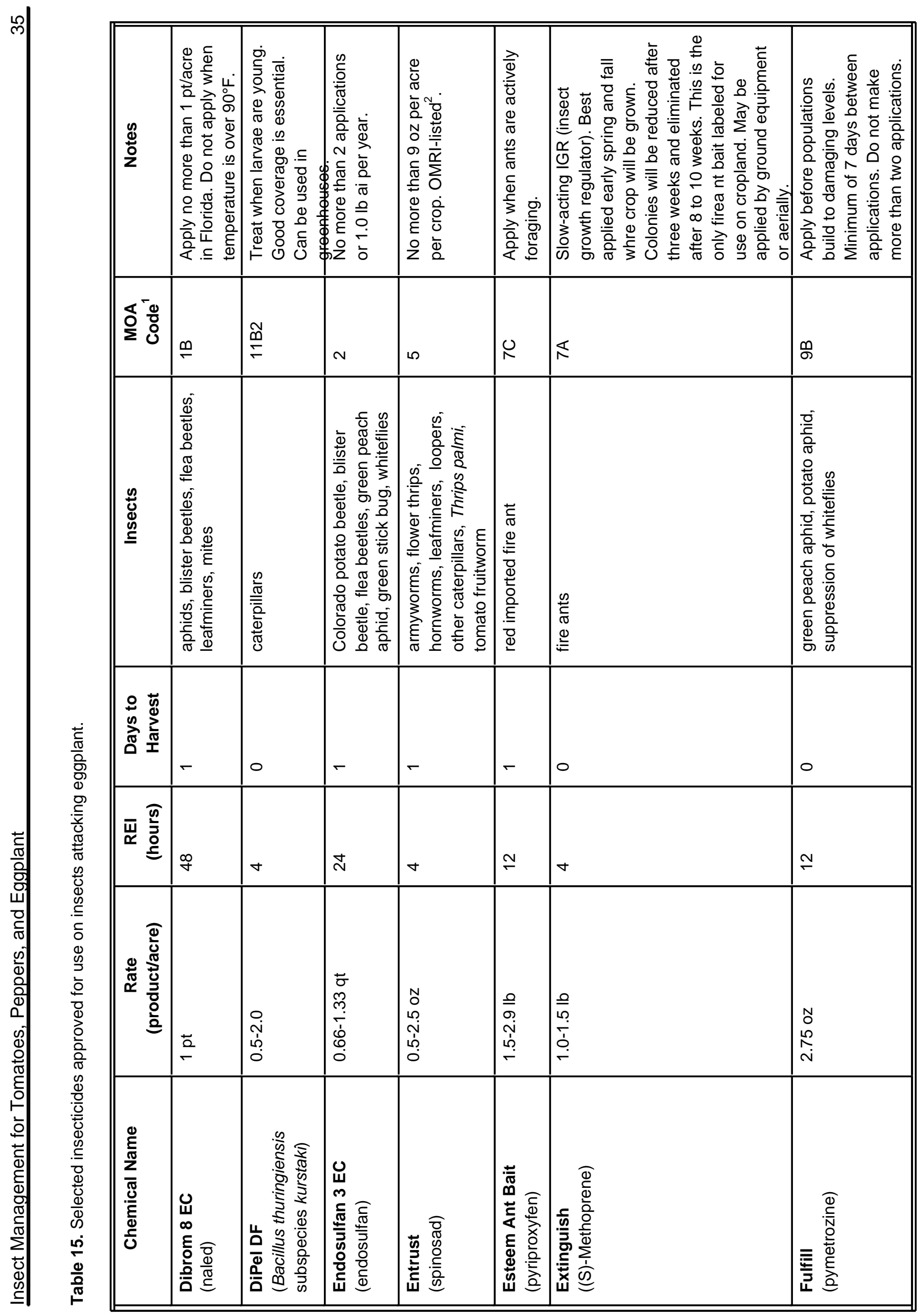




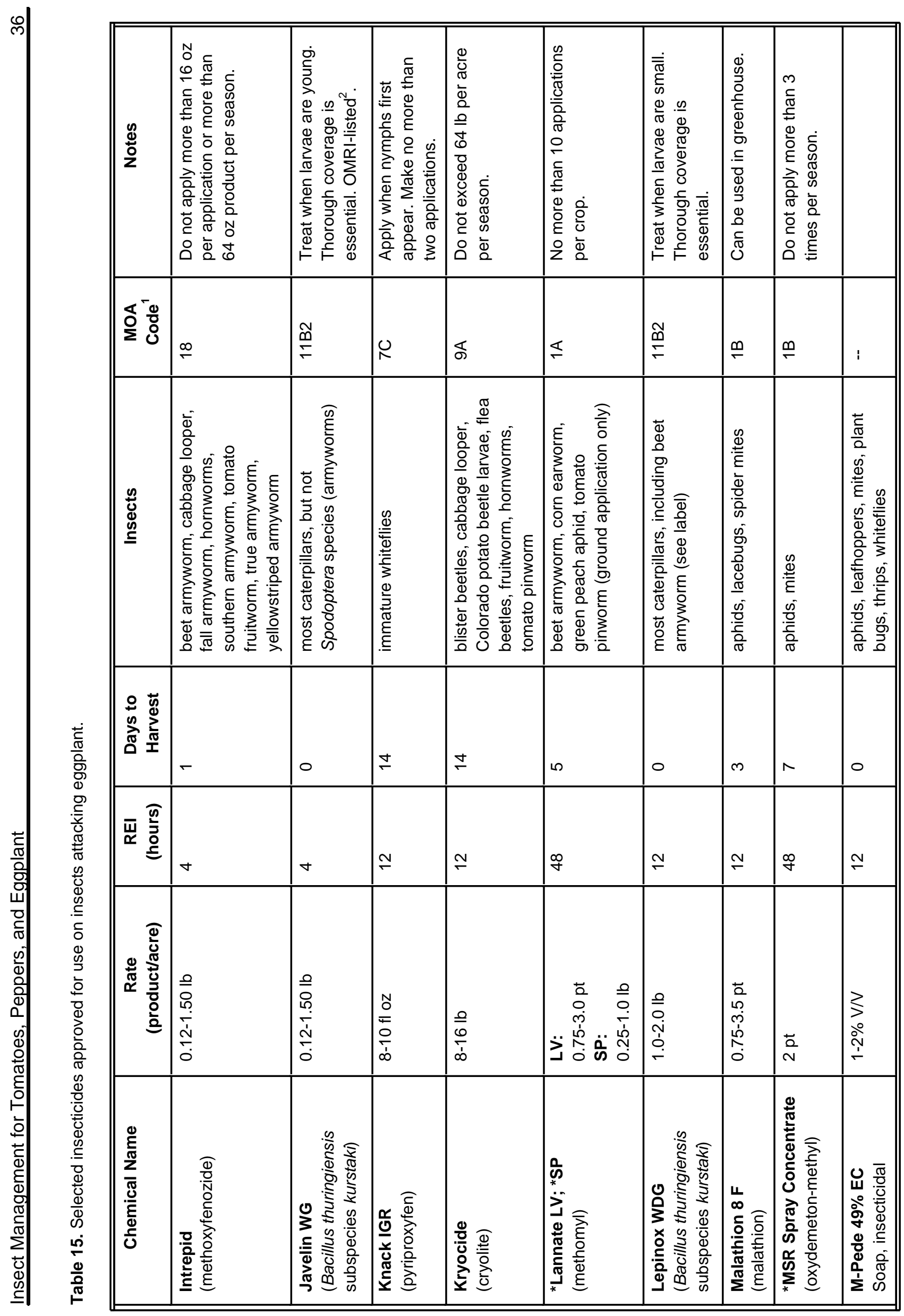




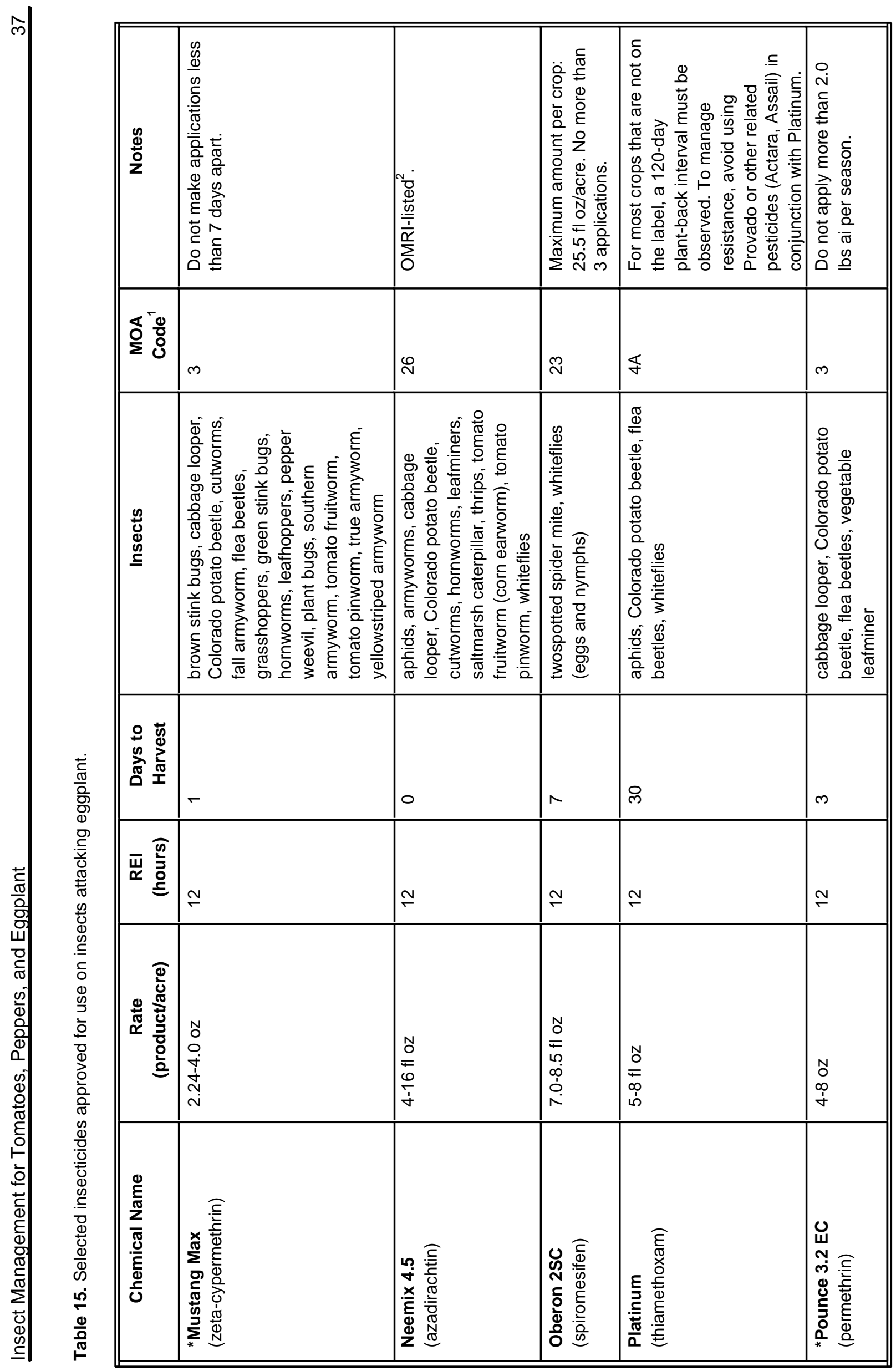




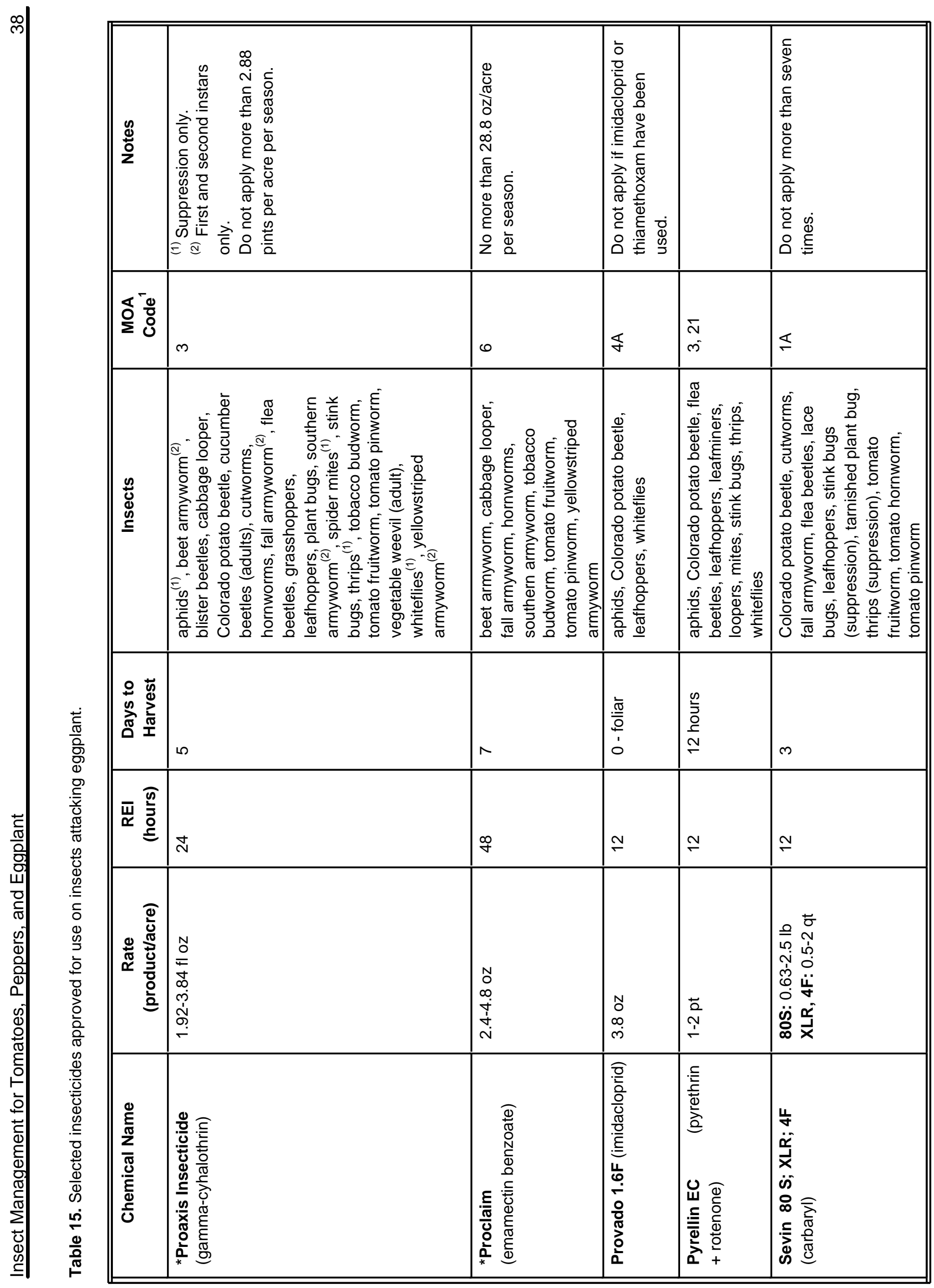




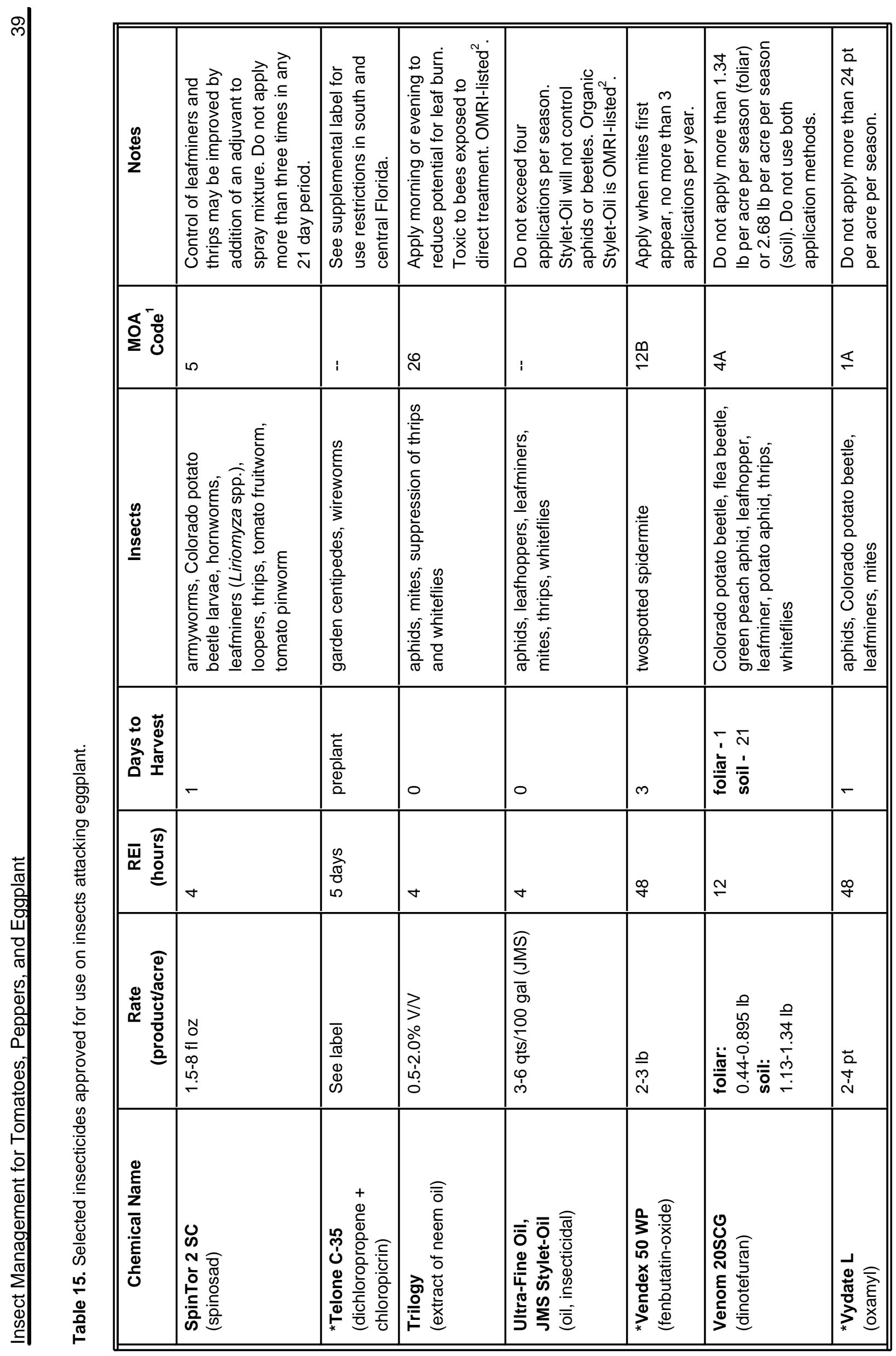




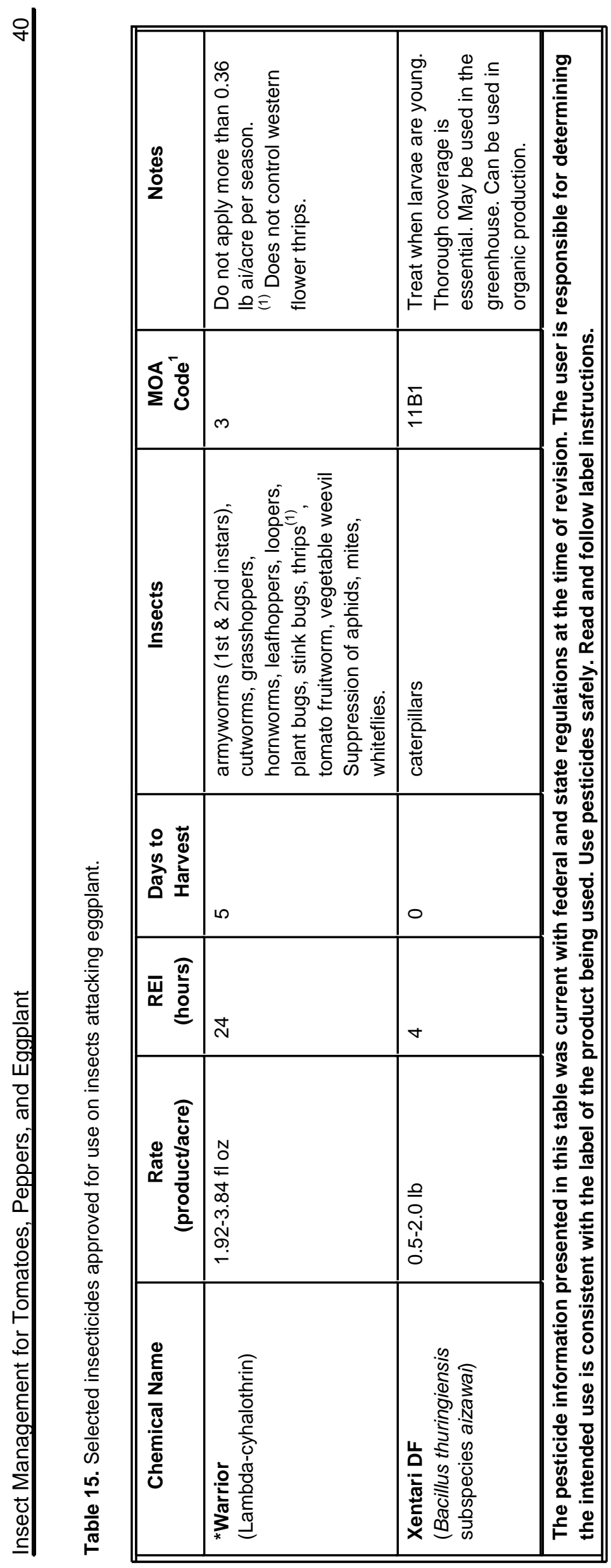




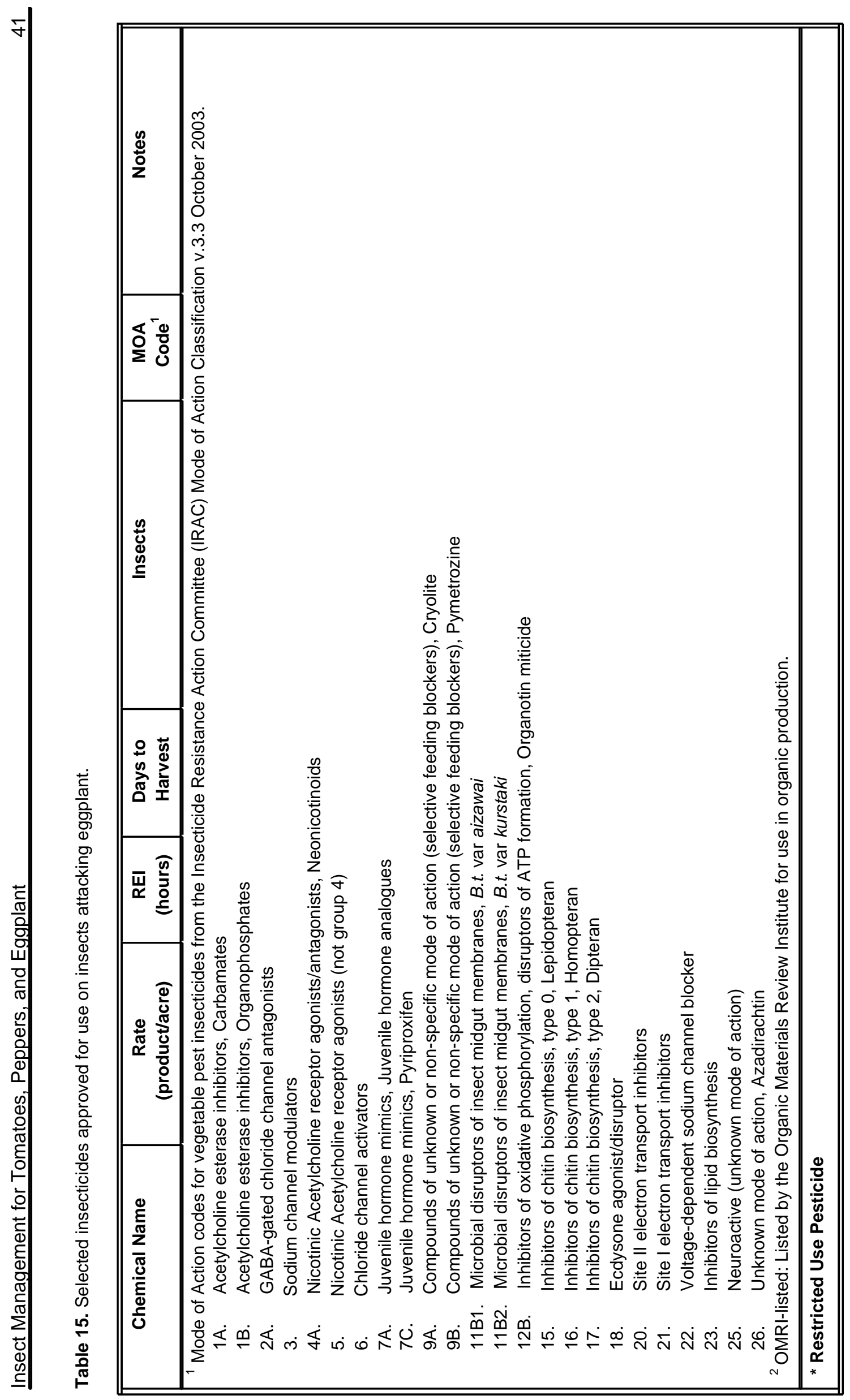

